\title{
Store-operated calcium entry and calcium influx via voltage-operated calcium channels regulate intracellular calcium oscillations in chondrogenic cells
}

\author{
a $\mathbf{1}$ János Fodor ${ }^{\mathrm{a}, 1},{ }^{2}$ Csaba Matta ${ }^{\mathrm{b}, 1}$, Tamás Oláh ${ }^{\mathrm{a}}$, Tamás Juhász ${ }^{\mathrm{b}}$, Roland Takács ${ }^{\mathrm{b}}$, Adrienn Tóth ${ }^{\mathrm{a}}$, \\ Beatrix Dienes ${ }^{\mathrm{a}}$, László Csernocha ${ }^{\mathrm{a}}$, Róza Zákány b,* \\ a Department of Physiology, Medical and Health Science Centre, University of Debrecen, Nagyerdei krt. 98, H-4032 Debrecen, Hungary \\ ${ }^{\mathrm{b}}$ Department of Anatomy, Histology and Embryology, Medical and Health Science Centre, University of Debrecen, Nagyerdei krt. $98, \mathrm{H}-4032$ Debrecen, Hungary
}

\section{A R T I C L E I N F O}

\section{Article history:}

Received 10 January 2013

Received in revised form 11 March 2013

Accepted 21 March 2013

Available online $\mathrm{xxx}$

\section{Keywords:}

SOCE

STIM

Orai1

Sox9

Proliferation

\begin{abstract}
A B S T R A C T
Chondrogenesis is known to be regulated by calcium-dependent signalling pathways in which temporal aspects of calcium homeostasis are of key importance. We aimed to better characterise calcium influx and release functions with respect to rapid calcium oscillations in cells of chondrifying chicken high density cultures. We found that differentiating chondrocytes express the $\alpha_{1}$ subunit of voltage-operated calcium channels (VOCCs) at both mRNA and protein levels, and that these ion channels play important roles in generating $\mathrm{Ca}^{2+}$ influx for oscillations as nifedipine interfered with repetitive calcium transients. Furthermore, VOCC blockade abrogated chondrogenesis and almost completely blocked cell proliferation. The contribution of internal $\mathrm{Ca}^{2+}$ stores via store-operated $\mathrm{Ca}^{2+}$ entry (SOCE) seems to be indispensable to both $\mathrm{Ca}^{2+}$ oscillations and chondrogenesis. Moreover, this is the first study to show the functional expression of STIM1/STIM2 and Orai1, molecules that orchestrate SOCE, in chondrogenic cells. Inhibition of SOCE combined with ER calcium store depletion abolished differentiation and severely diminished proliferation, suggesting the important role of internal pools in calcium homeostasis of differentiating chondrocytes. Finally, we present an integrated model for the regulation of calcium oscillations of differentiating chondrocytes that may have important implications for studies of chondrogenesis induced in various stem cell populations.
\end{abstract}

(C) 2013 Elsevier Ltd. All rights reserved.
Abbreviations: AM, acetoxy-methylester; ARC, arachidonate-regulated $\mathrm{Ca}^{2+}$ sensitive channel; ATP, adenosine triphosphate; CaMKII, $\mathrm{Ca}^{2+}$-calmodulin dependent protein kinase II; CPA, cyclopiazonic acid; CRAC, $\mathrm{Ca}^{2+}$ release-activated $\mathrm{Ca}^{2+}$ channel; CREB, CAMP-response element binding protein; DMMB, dimethylmethylene blue; ECM, extracellular matrix; ER, endoplasmic reticulum; FBS, foetal bovine serum; FTHM, full time at half maximum; HDC, high density cell culture; HRP, horse radish peroxidase; $\mathrm{IP}_{3}$, inositol-1,4,5-trisphosphate; $\mathrm{IP}_{3} \mathrm{R}$, inositol-1,4,5trisphosphate receptor; MSC, mesenchymal stem cell; NCX, $\mathrm{Na}^{+}-\mathrm{Ca}^{2+}$ exchanger; NFAT, nuclear factor of activated T lymphocytes; NMDA, $\mathrm{N}$-methyl-D-aspartate receptor; PKC, protein kinase C; PLC, phospholipase C; PMCA, plasma membrane $\mathrm{Ca}^{2+}$-ATPase; RMP, resting membrane potential; RT-PCR, reverse transcription followed by polymerase chain reaction; RyR, ryanodine receptor; SDS-PAGE, sodium dodecyl sulphate-polyacrylamide gel electrophoresis; SERCA, sarcoplasmic/endoplasmic reticulum $\mathrm{Ca}^{2+}$ ATPase; SOC, store-operated calcium channel; SOCE, store-operated $\mathrm{Ca}^{2+}$ entry; STIM, stromal interaction molecule; TB, toluidine blue; TRP, transient receptor potential receptor; TRPC, canonical transient receptor potential receptor; TRPV, transient receptor potential receptor vanilloid; VOCC, voltage-operated calcium channel.

* Corresponding author. Tel.: +36 52255 567; fax: +36 52255115 .

addresses: juhaszt@anat.med.unideb.hu(T. Juhász),

roza med.unideb.hu (R. Zákány).

1 inese authors contributed equally to the work.

\section{Introduction}

One of the initial steps during formation of the embryonic skeleton is the differentiation of chondroprogenitor cells into extracellular matrix-secreting chondroblasts. Later on, mature chondrocytes are formed that undergo terminal differentiation preceding endochondral ossification [1]. Cartilage formation, including differentiation and proliferation of chondrogenic cells, is tightly regulated by complex interplay between numerous families of signalling proteins, eventually leading to activation of Sox9, as well as Sox6 and L-Sox5-transcription factors that are essential for chondrogenesis; they are involved in the specification of the chondrogenic lineage and activate the expression of chondrogenic marker genes (e.g. COL2A1, AGR1) [2,3].

During the early steps of chondrogenesis, intracellular signalling undergoes profound changes to initiate specific gene activation that requires translocation of lineage-specific transcription factors into the cell nucleus. In particular, the nuclear localisation signal at the N-terminus of the chondrocyte-specific transcription factor Sox9 was shown to contain a calmodulin-binding region and $\mathrm{Ca}^{2+}$-calmodulin has been reported to be involved in the nuclear entry of Sox9 [4]. Calcium ions $\left(\mathrm{Ca}^{2+}\right)$ are suggested to be key 
42 factors involved in controlling differentiation of cells, including human mesenchymal stem cells (MSCs) [5] and chondrocytes [6].

In general, $\mathrm{Ca}^{2+}$-regulated cellular events require transiently elevated cytosolic $\mathrm{Ca}^{2+}$ concentration to activate $\mathrm{Ca}^{2+}$-sensitive signalling components [7]. Cells utilise two main sources of $\mathrm{Ca}^{2+}$ for initiating and generating signals. On the one hand, $\mathrm{Ca}^{2+}$ entry across the plasma membrane via either voltage-operated $\mathrm{Ca}^{2+}$ channels (VOCCs) or agonist-dependent and voltage-independent $\mathrm{Ca}^{2+}$ entry pathways, amongst which are the receptor ion channels (e.g. P2X [8], NMDA-receptors [9], TRPV channels [10]; the latter group also act as sensors of osmotic pressure, volume, stretch, and various chemical and mechanical stimuli [11]), the store-independent (e.g. arachidonate-dependent non-capacitive $\mathrm{Ca}^{2+}$ entry [12]) and 'store-operated' $\mathrm{Ca}^{2+}$ (SOC) channels (e.g. TRPs [5]); and on the other hand, $\mathrm{Ca}^{2+}$ release from internal stores such as the smooth endoplasmic reticulum (ER) via the inositol-1,4,5-trisphosphate receptor $\left(\mathrm{IP}_{3} \mathrm{R}\right)$ or the ryanodine receptor (RyR), as well as $\mathrm{Ca}^{2+}$ induced $\mathrm{Ca}^{2+}$ release (CICR) or via the exchange protein directly activated by cyclic AMP (Epac) $[13,14]$. Since changes of intracellular $\mathrm{Ca}^{2+}$ concentration are related to cell proliferation and differentiation that are important functions of undifferentiated cells such as MSCs, the $\mathrm{Ca}^{2+}$ homeostasis of stem cells has been thoroughly investigated [15].

It is well documented that different spatial and temporal patterns of intracellular free $\mathrm{Ca}^{2+}$ concentration play distinct roles in the regulation of various cellular processes. Not only a stable rise, but also periodic oscillatory changes of cytosolic $\mathrm{Ca}^{2+}$ concentration represent a nearly universal signalling mechanism even in non-excitable cells [16]. Signal transduction pathways triggered by $\mathrm{Ca}^{2+}$ oscillations are generally accepted to control cellular differentiation via reducing the threshold for the activation of different $\mathrm{Ca}^{2+}$-dependent transcription factors, including nuclear factor of activated T lymphocytes (NFAT), nuclear factor- $\kappa B$ (NF- $\kappa B$ ), Jun Nterminal kinase-1 (JNK1), myocyte enhancer factor-2 (MEF2) and the cAMP-response element binding protein (CREB), depending on the frequency and amplitude of the $\mathrm{Ca}^{2+}$ transients $[17,18]$. Spontaneous $\mathrm{Ca}^{2+}$ oscillations were reported in several non-excitable cells undergoing differentiation or proliferation [19]. In human MSCs, the major source of $\mathrm{Ca}^{2+}$ for the observed oscillations is $\mathrm{Ca}^{2+}$ release from ER via $\mathrm{IP}_{3} \mathrm{Rs}$, but $\mathrm{Ca}^{2+}$ influx via non-capacitive SOCs is also required to sustain these oscillations, without a significant contribution from VOCCs [5]. Unlike MSCs, spontaneous $\mathrm{Ca}^{2+}$ oscillations in most of the cells examined, including differentiating limb budderived mesenchymal cells, seemed to depend on the availability of extracellular $\mathrm{Ca}^{2+}$. These observations are in a good correlation with our previous results implying that mainly $\mathrm{Ca}^{2+}$ influx, at least in part via the ligand-gated purinergic cation channel $\mathrm{P} 2 \mathrm{X}_{4}$, is required for maintaining sustained raised cytosolic $\mathrm{Ca}^{2+}$ levels in differentiating chondrogenic cells $[20,21]$. Nevertheless, in these studies, the contribution from internal $\mathrm{Ca}^{2+}$ stores, in spite of the functional expression of $\mathrm{IP}_{3} \mathrm{Rs}$, seemed to be less important in differentiating chicken chondrogenic cells. Many $\mathrm{Ca}^{2+}$ entry and release processes have been documented in mature chondrocytes [22]; however, knowledge regarding the precise regulation and function of $\mathrm{Ca}^{2+}$ homeostasis, including high-frequency spontaneous oscillations, during in vitro chondrogenesis is still sparse.

In this study, we aimed at further characterising the $\mathrm{Ca}^{2+}$ homeostasis of differentiating chicken chondrocytes with special emphasis on the contribution of internal $\mathrm{Ca}^{2+}$ stores and the involvement of VOCCs in generating and maintaining highfrequency repetitive $\mathrm{Ca}^{2+}$ transients to modulate cellular functions such as differentiation and proliferation. We undertook to analyse intracellular $\mathrm{Ca}^{2+}$ dynamics in individual chondrifying cells at high spatial and temporal resolution using LIVE confocal $\mathrm{Ca}^{2+}$ imaging microscopy. Having performed a detailed investigation of the contribution of internal $\mathrm{Ca}^{2+}$ stores and store-operated $\mathrm{Ca}^{2+}$ entry
(SOCE) to the $\mathrm{Ca}^{2+}$ homeostasis of differentiating chondrocytes and the involvement of $\mathrm{Ca}^{2+}$ influx via VOCCs in generating or maintaining spontaneous $\mathrm{Ca}^{2+}$ oscillations, we provide a refined model of $\mathrm{Ca}^{2+}$ signalling events including $\mathrm{Ca}^{2+}$ influx and release functions in differentiating cells of chondrifying micromass cultures during in vitro chondrogenesis.

\section{Materials and methods}

\subsection{Primary high density chondrifying cell cultures}

A well-known and easily reproducible in vitro experimental model to study hyaline cartilage formation was first described by Ahrens et al. [23]. In these high density cell cultures (HDC), chicken limb bud-derived chondroprogenitor mesenchymal cells spontaneously differentiate to chondroblasts and chondrocytes on days 2 and 3 of culturing, and a well-detectable amount of hyaline cartilage extracellular matrix (ECM) is produced by day 6 .

To establish primary micromass cell cultures of chondrifying mesenchymal cells, Ross hybrid chicken embryos of Hamburger-Hamilton developmental stages 22-24 (4.5-day-old) were used. Work on early chick embryos in vitro does not require a license from the Ethics Committee of the University of Debrecen. Distal parts of forelimbs and hindlimbs of embryos were isolated and dissociated in $0.25 \%$ trypsin-EDTA (Sigma, St. Louis, MO, USA; $\mathrm{pH} 7.4$ ) at $37^{\circ} \mathrm{C}$ for $1 \mathrm{~h}$. The enzymatic digestion was terminated by the addition of equal volume of foetal bovine serum (FBS; Gibco, Gaithersburg, MD, USA) and digested limb buds were filtered through a $20-\mu \mathrm{m}$ pore size plastic filter unit (Millipore, Billerica, MA, USA) to yield a single cell suspension of chondrogenic mesenchymal cells. After a brief centrifugation (at $800 \times g$ for $10 \mathrm{~min}$ ), cells were resuspended in Ham's F12 medium (Sigma) supplemented with $10 \%$ FBS at a concentration of $1.5 \times 10^{7} \mathrm{cells} \mathrm{mL}^{-1}$ and $100-100 \mu \mathrm{L}$ droplets were inoculated into plastic cell culture plates (Orange Scientifique, Braine-l'Alleud, Belgium). After allowing the cells to attach to the surface for $120 \mathrm{~min}$ at $37^{\circ} \mathrm{C}$ in a $\mathrm{CO}_{2}$ incubator (5\% $\mathrm{CO}_{2}$ and $80 \%$ humidity), $2 \mathrm{~mL}$ of Ham's F12 supplemented with $10 \%$ FBS, $0.5 \mathrm{mM}$ stabile L-glutamine and antibiotics/antimicotics (penicillin $50 \mathrm{U} \mathrm{mL}^{-1}$, streptomycin $50 \mu \mathrm{g} \mathrm{mL}^{-1}$, fungizone $1.25 \mu \mathrm{g} \mathrm{mL}^{-1}$; TEVA, Debrecen, Hungary) was added. Day of inoculation was considered as day 0 of culturing. Cultures were kept at $37^{\circ} \mathrm{C}$ in a $\mathrm{CO}_{2}$ incubator for 6 days. The medium was changed on every second day.

\subsection{Confocal microscopy}

\subsubsection{Line-scan analysis}

Spontaneous $\mathrm{Ca}^{2+}$ transients and the effects of modified extracellular ionic milieu or various drugs on $\mathrm{Ca}^{2+}$ oscillations were monitored using an LSM 510 META Laser Scanning Confocal Microscope (Zeiss, Oberkochen, Germany). All measurements were performed at room temperature. Cells of 1- and 2-day-old high density micromass cell cultures were incubated for $30 \mathrm{~min}$ at $37^{\circ} \mathrm{C}$ with $10 \mu \mathrm{M}$ Fluo-4-AM in Ham's F12 medium. Calcium imaging was carried out in normal (in mM: $137 \mathrm{NaCl}, 5.4 \mathrm{KCl}, 0.5$ $\mathrm{MgCl}_{2}, 1.8 \mathrm{CaCl}_{2}, 11.8$ HEPES; $1 \mathrm{~g} \mathrm{~L}^{-1}$ glucose; $\mathrm{pH}$ 7.4) or $\mathrm{Ca}^{2+}$-free (containing 5 mM EGTA, without $\mathrm{CaCl}_{2}$ ) Tyrode's solution. The sarcoplasmic/endoplasmic reticulum $\mathrm{Ca}^{2+}$-ATPase (SERCA) inhibitor cyclopiazonic acid (CPA, Sigma) was used at a final concentration of $10 \mu \mathrm{M}$ in normal Tyrode's solution (stock: $10 \mathrm{mM}$, in DMSO). SOCE blockers, i.e. the non-specific TRPC antagonist YM-58483 (a pyrazole derivative, also known as BTP-2; Sigma) [24] and $\mathrm{LaCl}_{3}$ (Sigma) [5] were used at $1 \mu \mathrm{M}$ and $500 \mu \mathrm{M}$ final concentrations, respectively, diluted in normal Tyrode's solution (stocks: $300 \mathrm{mM}$ and $1 \mathrm{mM}$ in distilled water and DMSO, respectively). 
(These compounds could not be applied to oscillating cells in $\mathrm{Ca}^{2+}$ free Tyrode's since removal of free extracellular $\mathrm{Ca}^{2+}$ ions alone abolished $\mathrm{Ca}^{2+}$ oscillations, which would have rendered the evaluation of the effects of these blockers impossible.) Acquisition of line-scan images started immediately after changing the solution on the cultures. During measurements, only cells exhibiting $\mathrm{Ca}^{2+}$ oscillations were investigated, and other cells were disregarded. Line-scan images were acquired at $0.8 \mathrm{~ms} /$ line, 512 pixels/line with $7 \mathrm{~ms}$ intervals, recording 8192 lines using a $63 \times$ water immersion objective. Measurements were carried out in cells from 3 independent experiments. Images were analysed using an automatic event detection software developed in the Department of Physiology of the University of Debrecen, Medical and Health Science Centre.

\subsection{2. $X-Y$ monitoring}

Series of $X-Y$ images were recorded from random visual fields of 1- and 2-day-old Fluo-4-loaded chondrifying cultures with LIVE 5 Laser Scanning Confocal Microscope (Zeiss, Oberkochen, Germany) using EC Plan-Neofluar $20 \times / 0.50$ M27 objective with $2 \times$ digital zoom. Calcium imaging was performed in normal and $\mathrm{Ca}^{2+}$-free Tyrode's solutions (see above). All measurements were performed at room temperature. $\mathrm{LaCl}_{3}(500 \mu \mathrm{M}), \mathrm{YM}-58483(1 \mu \mathrm{M})$, and nifedipine $(10 \mu \mathrm{M})$ were diluted in normal Tyrode's solution (containing $1.8 \mathrm{mM} \mathrm{Ca}^{2+}$; see above). Frame acquisition rate was $10 \mathrm{~s}^{-1}$. A total number of 1000 images were recorded during control conditions on days 1 and 2. When the effects of pharmacons on spontaneous $\mathrm{Ca}^{2+}$ transients were examined during time series recordings, the same visual fields on each culture were observed 1, 3 and 5 min after replacing the bath solution from normal Tyrode's to the test solution $\left(\mathrm{LaCl}_{3}-\mathrm{YM}-58483\right.$; or nifedipine). During these latter experiments, a total number of $500 \mathrm{X}-\mathrm{Y}$ scans were recorded at each time point. Data analysis was carried out using Zeiss Enhanced Navigation (ZEN 2009) software. The round-shaped chondrocytes were marked as region of interest (ROI) on each visual field. Timedependent fluorescent intensities of ROIs were analysed using an automatic event detection software developed in the Department of Physiology.

\subsection{Single cell fluorescent $\mathrm{Ca}^{2+}$ measurements}

Measurements were performed on day 2 of culturing using the calcium dependent fluorescent dye Fura-2 as described previously [6]. Briefly, cultures were transferred to $2 \mathrm{~mL}$ fresh Ham's F12 medium containing $10 \mu \mathrm{L}$ Fura-2-acetoxy-methylester (AM; $10 \mu \mathrm{M})$ and $4 \mu \mathrm{L}$ neostigmin $(0.3 \mathrm{nM}$; to inhibit extracellular choline-esterase activity). Fura-2-loaded cells were then placed on the stage of an inverted fluorescent microscope (Diaphot; Nikon, Kowasaki, Japan) and viewed using a $40 \times$ oil immersion objective. Measurements were performed in normal and $\mathrm{Ca}^{2+}$-free Tyrode's solutions (see above). $\mathrm{LaCl}_{3}(500 \mu \mathrm{M}), \mathrm{YM}-58483(1 \mu \mathrm{M})$, and CPA $(10 \mu \mathrm{M})$ were diluted in $\mathrm{Ca}^{2+}$-free Tyrode's solution. Excitation wavelength was altered between 340 and $380 \mathrm{~nm}\left(F_{340}\right.$ and $\left.F_{380}\right)$ by a microcomputer-controlled dual-wavelength monochromator (DeltaScan; Photon Technologies International, New Brunswick, NJ, USA). Emission was monitored at $510 \mathrm{~nm}$ at $10 \mathrm{~Hz}$ acquisition rate using a photomultiplier. Background fluorescence was subtracted on-line from $F_{340}$ and $F_{380}$ signals by the data acquisition software.

Intracellular $\left[\mathrm{Ca}^{2+}\right]$ was calculated from the ratio of measured fluorescence intensities $\left(R=F_{340} / F_{380}\right)$ as described by Grynkiewicz et al. [25]. The measuring bath was constantly perfused with normal Tyrode's solution at a rate of $2 \mathrm{~mL} \mathrm{~min}^{-1}$ (EconoPump; Bio-Rad Laboratories, CA, USA). Test solutions were directly applied to the cells through a perfusion capillary tube (Perfusion Pencil ${ }^{\mathrm{TM}}$; AutoMate Scientific, San Francisco, CA, USA) with an internal diameter of $250 \mu \mathrm{m}$ at a rate of $1.5 \mu \mathrm{L} \mathrm{s}^{-1}$, using a local perfusion system (Valve
Bank $^{\mathrm{TM}} 8$ version 2.0, AutoMate Scientific). All measurements were performed at room temperature.

\subsection{Modulation of $\mathrm{Ca}^{2+}$ influx via voltage-operated $\mathrm{Ca}^{2+}$ channels with nifedipine and inhibition of SOCE}

In order to assess longer-term effects of interference with $\mathrm{Ca}^{2+}$ homeostasis of differentiating chondrocytes, the above compounds were also added to the culture medium of HDC. The L-type VOCCblocker nifedipine was administered to the culture medium from the beginning of the first culturing day at a final concentration of $10 \mu \mathrm{M}$. For control experiments, the vehicle (DMSO, Sigma) was added to cultures at equal volumes. To assess the role of internal $\mathrm{Ca}^{2+}$ stores, following store depletion with $10 \mu \mathrm{M}$ CPA, SOCE was blocked by co-application of $1 \mu \mathrm{M}$ YM-58483 and $500 \mu \mathrm{M}$ $\mathrm{LaCl}_{3}$. CPA, YM-58483 and $\mathrm{LaCl}_{3}$ were added to the culture medium on culturing day 2 for $24 \mathrm{~h}$. For control experiments, the vehicles (DMSO and sterile water) were added to cultures at equal volumes.

\subsection{Qualitative and semi-quantitative determination of cartilage matrix production}

For visualisation of cartilage matrix in HDC, low pH metachromatic staining was performed with dimethyl methylene blue (DMMB; Sigma) dissolved in 3\% acetic acid on day 6 of culturing. The amount of sulphated matrix components was determined with a semi-quantitative method, by measuring the optical density of extracted toluidine blue (TB; Reanal, Budapest, Hungary) bound to glycosaminoglycans in 6-day-old HDC. Both qualitative and semi-quantitative staining procedures were described previously in more detail [6].

\subsection{Measurement of cell proliferation and mitochondrial activity}

Rate of cellular proliferation in HDC was determined by measuring the radioactivity of incorporated ${ }^{3} \mathrm{H}$-thymidine during a 16-h-long period on day 3 (as described earlier [6]) started promptly after combined treatment with CPA, YM-58483 and $\mathrm{LaCl}_{3}$, or nifedipine. For the investigation of mitochondrial activity, cells cultured in wells of 96-well plates were used and MTT-assay was performed immediately after treatments on day 3 as it was described previously [6]. Untreated 3-day-old HDC were used as controls for both assays. Measurements were carried out in 6 samples of each experimental group in 3 independent experiments.

\subsection{Reverse transcription followed by PCR analysis}

Total RNA from HDC was isolated as described previously [6]. The assay mixture $(20 \mu \mathrm{L})$ for reverse transcriptase $(\mathrm{RT})$ reactions contained $500 \mathrm{ng}$ total RNA, $0.25 \mu \mathrm{L}$ RNase inhibitor, $2 \mu \mathrm{L}$ random primers, $0.8 \mu \mathrm{L}$ dNTP Mix $(4 \mathrm{mM}), 50$ units $(1 \mu \mathrm{L})$ MultiScribe $^{\mathrm{TM}}$ RT in $1 \times$ RT buffer (High Capacity RT kit; Applied Biosystems, Foster City, CA, USA) and complementary cDNA was transcribed at $37^{\circ} \mathrm{C}$ for $2 \mathrm{~h}$. Amplifications of specific cDNA sequences were achieved with specific primer pairs that were designed based on chicken nucleotide sequences published in GenBank and purchased from Integrated DNA Technologies, Inc. (IDT; Coralville, IA, USA). Nucleotide sequences of forward and reverse primers and reaction conditions are shown in Table 1 . PCR reactions were carried out in a final volume of $25 \mu \mathrm{L}$ containing $1-1 \mu \mathrm{L}$ forward and reverse primers $(10 \mu \mathrm{M}), 0.5 \mu \mathrm{L}$ cDNA, $0.5 \mu \mathrm{L}$ dNTP Mix $(200 \mu \mathrm{M})$, and 1 unit $(0.2 \mu \mathrm{L})$ Promega GoTaq ${ }^{\circledR}$ DNA polymerase in $1 \times$ Green GoTaq ${ }^{\circledR}$ Reaction Buffer in a programmable thermal cycler (Labnet MultiGene ${ }^{\mathrm{TM}}$ 96-well Gradient Thermal Cycler; Labnet International, Edison, NJ, USA) with the following settings: 2 min at $95^{\circ} \mathrm{C}$ 
Table 1

Nucleotide sequences, amplification sites, GenBank accession numbers, amplicon sizes and PCR reaction conditions for each primer pair are shown.

\begin{tabular}{|c|c|c|c|c|c|}
\hline Gene & Primer & Nucleotide sequence $\left(5^{\prime} \rightarrow 3^{\prime}\right)$ & GenBank ID & $\begin{array}{l}\text { Annealing } \\
\text { temperature }\end{array}$ & $\begin{array}{l}\text { Amplicon size } \\
\text { (bp) }\end{array}$ \\
\hline $\mathrm{Ca}_{\mathrm{V}} 1.2$ (CACNA1C) & $\begin{array}{l}\text { Sense } \\
\text { Antisense }\end{array}$ & $\begin{array}{l}\text { CAA CAG AGC CAA AGG ACT AAA }(3054-3074) \\
\text { GTG ACG ATG ACG AAA CCA A }(3512-3530)\end{array}$ & XM_416388 & $54^{\circ} \mathrm{C}$ & 477 \\
\hline $\mathrm{Ca}_{\mathrm{V}} 1.3$ (CACNA1D) & $\begin{array}{l}\text { Sense } \\
\text { Antisense }\end{array}$ & $\begin{array}{l}\text { AGG CTC ATC AAT CAC CAC A (2704-2722) } \\
\text { AAA GAC GCA CTG AAC AAC G }(3072-3090)\end{array}$ & NM_205034 & $54^{\circ} \mathrm{C}$ & 387 \\
\hline Cav2.2 (CACNA1B) & $\begin{array}{l}\text { Sense } \\
\text { Antisense }\end{array}$ & $\begin{array}{l}\text { CTA CGC CAC GAC CCT ACA C (2442-2460) } \\
\text { TTC TCA ACG CCT TCT TCC A }(2831-2849)\end{array}$ & NM_204293 & $61{ }^{\circ} \mathrm{C}$ & 408 \\
\hline Cav2.3 (CACNA1E) & $\begin{array}{l}\text { Sense } \\
\text { Antisense }\end{array}$ & $\begin{array}{l}\text { TCA CCA ACT CCG ACC GTA AC }(3347-3366) \\
\text { CAC CTC CAT CTT GTT CTT CTC AT }(3824-3846)\end{array}$ & XM_422255 & $60^{\circ} \mathrm{C}$ & 500 \\
\hline Cav3.1 (CACNA1G) & $\begin{array}{l}\text { Sense } \\
\text { Antisense }\end{array}$ & $\begin{array}{l}\text { CAC TGA ATC CGT CCA TAG CAT C (1989-2010) } \\
\text { CTG TCT GAG TCC GTC TCG TTG T }(2390-2411)\end{array}$ & XM_001232653 & $61{ }^{\circ} \mathrm{C}$ & 423 \\
\hline $\mathrm{Ca}_{\mathrm{V}} 3.2(\mathrm{CACNA} 1 \mathrm{H})$ & $\begin{array}{l}\text { Sense } \\
\text { Antisense }\end{array}$ & $\begin{array}{l}\text { CCC TGG AAG GAT GGG TTG A (1256-1274) } \\
\text { CTG CCC GTT TGT GGT GTT G (1608-1626) }\end{array}$ & XM_414830 & $61^{\circ} \mathrm{C}$ & 371 \\
\hline $\mathrm{Ca}_{\mathrm{V}} 3.3$ (CACNA1I) & $\begin{array}{l}\text { Sense } \\
\text { Antisense }\end{array}$ & $\begin{array}{l}\text { CTG AGG ACG GAT ACA GGA GAT (2281-2301) } \\
\text { TTG CGT GAA GAG TTG GAG AC }(2698-2717)\end{array}$ & XM_425474 & $59^{\circ} \mathrm{C}$ & 437 \\
\hline Orai1 & $\begin{array}{l}\text { Sense } \\
\text { Antisense }\end{array}$ & $\begin{array}{l}\text { TAG CAA CGT GCA TAA TCT CAA }(264-284) \\
\text { TCA GTC CAA AGG GAA CCA T }(502-520)\end{array}$ & NM_001030658 & $57^{\circ} \mathrm{C}$ & 257 \\
\hline STIM1 & $\begin{array}{l}\text { Sense } \\
\text { Antisense }\end{array}$ & $\begin{array}{l}\text { GGT GGT GTC CAT CGT CAT CG (426-445) } \\
\text { GCT CCT TCT CGG CGT TCT TC (762-781) }\end{array}$ & NM_001030838 & $62{ }^{\circ} \mathrm{C}$ & 356 \\
\hline STIM2 & $\begin{array}{l}\text { Sense } \\
\text { Antisense }\end{array}$ & $\begin{array}{l}\text { CAA TTA GCA ATC GCC AAA G }(1177-1195) \\
\text { CAC AGA AAG GAT GTC AGG GT }(1652-1671)\end{array}$ & XM_420749 & $57^{\circ} \mathrm{C}$ & 495 \\
\hline $\begin{array}{l}\text { Aggrecan core protein } \\
\text { (AGR1) }\end{array}$ & $\begin{array}{l}\text { Sense } \\
\text { Antisense }\end{array}$ & $\begin{array}{l}\text { CAA TGC AGA GTA CAG AGA }(276-294) \\
\text { TCT GTC TCA CGG ACA CCG }(688-704)\end{array}$ & XM_001232949 & $54^{\circ} \mathrm{C}$ & 430 \\
\hline Collagen II (COL2A1) & $\begin{array}{l}\text { Sense } \\
\text { Antisense }\end{array}$ & $\begin{array}{l}\text { GGA CCC AAA GGA CAG ACG G }(1191-1210) \\
\text { TCG CCA GGA GCA CCA GTT }(1573-1591)\end{array}$ & NM_204426 & $59^{\circ} \mathrm{C}$ & 401 \\
\hline Sox9 & $\begin{array}{l}\text { Sense } \\
\text { Antisense }\end{array}$ & $\begin{array}{l}\text { CCC CAA CGC CAT CTT CAA }(713-731) \\
\text { CTG CTG ATG CCG TAG GTA }(1075-1093)\end{array}$ & NM_204281 & $54^{\circ} \mathrm{C}$ & 381 \\
\hline GAPDH & $\begin{array}{l}\text { Sense } \\
\text { Antisense }\end{array}$ & $\begin{array}{l}\text { GAG AAC GGG AAA CTT GTC AT }(238-258) \\
\text { GGC AGG TCA GGT CAA CAA }(775-793)\end{array}$ & NM_204305 & $54^{\circ} \mathrm{C}$ & 556 \\
\hline
\end{tabular}

for initial denaturation followed by 35 repeated cycles of denaturation at $94{ }^{\circ} \mathrm{C}$ for $30 \mathrm{~s}$, primer annealing for $45 \mathrm{~s}$ at an optimised temperature for each primer pair (see Table 1 ), and extension at $72^{\circ} \mathrm{C}$ for $90 \mathrm{~s}$. After the final cycle, further extension was allowed to proceed for another $7 \mathrm{~min}$ at $72{ }^{\circ} \mathrm{C}$. PCR products were analysed using a $1.2 \%$ ethidium bromide-containing agarose gel. Optical density of PCR product signals was determined by using ImageJ (Image Processing and Analysis in Java) version 1.46 freeware (http://rsbweb.nih.gov/ij/).

\subsection{SDS-PAGE and Western blot analysis}

Total cell lysates of HDC for sodium dodecyl sulphate-polyacrylamide gel electrophoresis (SDS-PAGE) were prepared as described previously [26]. $50 \mu \mathrm{g}$ of protein was separated by $7.5 \%$ SDS-PAGE gel for immunological detection of key proteins for $\mathrm{Ca}^{2+}$ influx or release functions (i.e. pan $\alpha_{1}$ subunit of voltage-gated $\mathrm{Ca}^{2+}$ channels and STIM1), as well as protein expression and phosphorylation status of the chondrogenic master transcription factor Sox9. Proteins were transferred electrophoretically to nitrocellulose membranes. After blocking in 5\% non-fat dry milk in PBS, membranes were incubated with primary antibodies overnight at $4{ }^{\circ} \mathrm{C}$ as follows: rabbit polyclonal anti-Cav pan $\alpha_{1}$ subunit in 1:200, epitope: intracellular C-terminus (Alomone Labs, Jerusalem, Israel); and mouse monoclonal anti-STIM1 in 1:500, epitope: $25-139$ in human that has a high similarity to the chicken sequence (BD Biosciences, Franklin Lakes, NJ, USA); rabbit polyclonal anti-Sox9 antibody (Abcam, Cambridge, UK) in 1:600; rabbit polyclonal anti-P-Sox9 antibody (Sigma) in 1:800; rabbit polyclonal anti-actin antibody (Santa Cruz Biotechnology, Inc., Santa Cruz, CA, USA) and rabbit polyclonal anti-GAPDH antibody
(Abcam). After washing for $30 \mathrm{~min}$ in PBST, membranes were incubated with the HRP-conjugated secondary antibody, anti-rabbit IgG (Bio-Rad) in 1:1500 dilution. Membranes were developed by enhanced chemiluminescence reaction (Millipore, Billerica, MA, USA) according to the instructions of the manufacturer. Optical density of signals was measured by using ImageJ 1.46 .

\subsection{Statistical analysis}

All data are representative of at least three independent experiments. Averages are expressed as mean \pm SEM (standard error of the mean; $n$, number of cells measured). Statistical analysis was performed by using Student's $t$-test. Threshold for statistically significant differences as compared to respective control cultures was set at ${ }^{*} P<0.05$.

\section{Results}

\subsection{Rapid spontaneous $\mathrm{Ca}^{2+}$ oscillations are detectable in} differentiating chondrocytes

To investigate spontaneous repetitive transient increases in cytosolic $\mathrm{Ca}^{2+}$ concentration in individual cells of primary chondrifying micromass cultures derived from embryonic limb buds, Fluo-4 fluorescent $\mathrm{Ca}^{2+}$ imaging technique was applied on days 1 and 2 using LIVE confocal microscopy. As these cultures are heterogeneous by nature in terms of cellular composition (epithelial cells and muscle progenitors with distinct morphology can also be found in relatively small numbers along with osteochondroprogenitor cells; see [21]), only cells with round morphology were included in this study, while others were disregarded. Series of X-Y images 

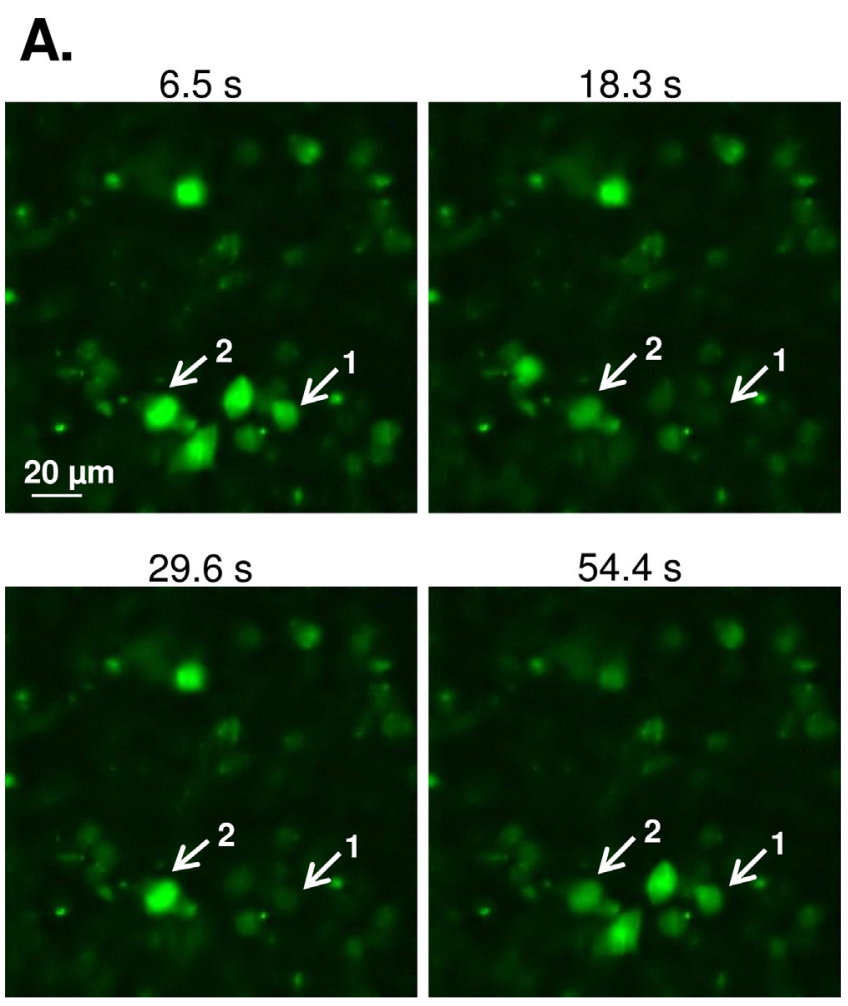

B.

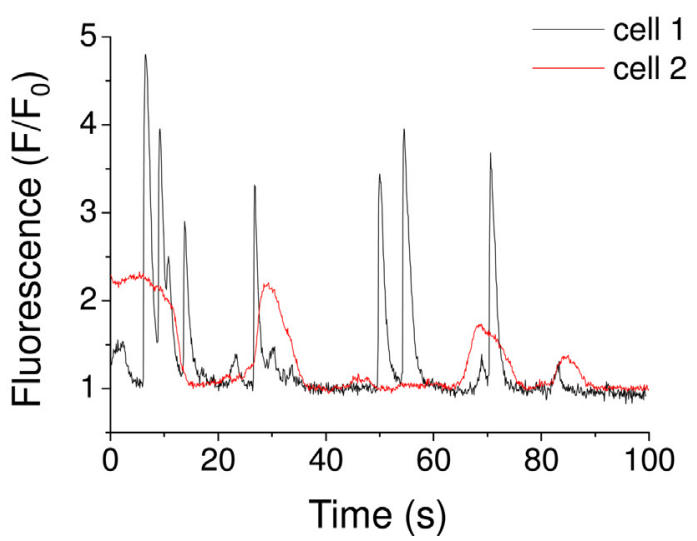
measurements, cells were loaded with Fluo-4-AM for $30 \mathrm{~min} \mathrm{Ca}^{2+}$ oscillations were observed without agonist stimulation in Tyrode's solution containing $1.8 \mathrm{mM} \mathrm{Ca}^{2+}$ at room temperature. (A) Series of X-Y images were recorded from random visual fields of chondrifying cultures with Zeiss LIVE 5 Laser Scanning Confocal Microscope. These four representative frames were acquired at 6.5, 18.3, 29.6 and $54.4 \mathrm{~s}$ during measurements. Arrows indicate differentiating chondrocytes with repetitive intracellular $\mathrm{Ca}^{2+}$ oscillations. (B) Time course of fluorescence intensities of the cells marked with arrows in panel (A). Fluo-4 fluorescence intensity values normalised to baseline fluorescence $\left(F / F_{0}\right)$ are plotted $v s$. time. Wide ranges of frequency and amplitude of oscillating cells were observed.

recorded from random visual fields of Fluo-4-loaded chond fying cultures on days 1 and 2 of culturing. $\mathrm{Ca}^{2+}$ oscillations were recorded from cells bathed in Tyrode's solution containing $1.8 \mathrm{mM}$ $\mathrm{Ca}^{2+}$ without agonist stimulation at room temperature. Four representative $\mathrm{X}-\mathrm{Y}$ images recording Fluo-4-loaded cells in a 2-day-old culture taken at 6.5, 18.3, 29.6 and $54.4 \mathrm{~s}$ during measurements are shown in Fig. 1A. Wide ranges of frequency and amplitude of oscillating cells were observed (Fig. 1B; see Supplementary Video). On culturing day 1, 45 of 240 cells investigated (19\%) exhibited spontaneous $\mathrm{Ca}^{2+}$ oscillations; whereas on day 2 , the proportion
Fig. 1. Spontaneous $\mathrm{Ca}^{2+}$ oscillations in cells of HDC on day 2 of culturing. Prior to
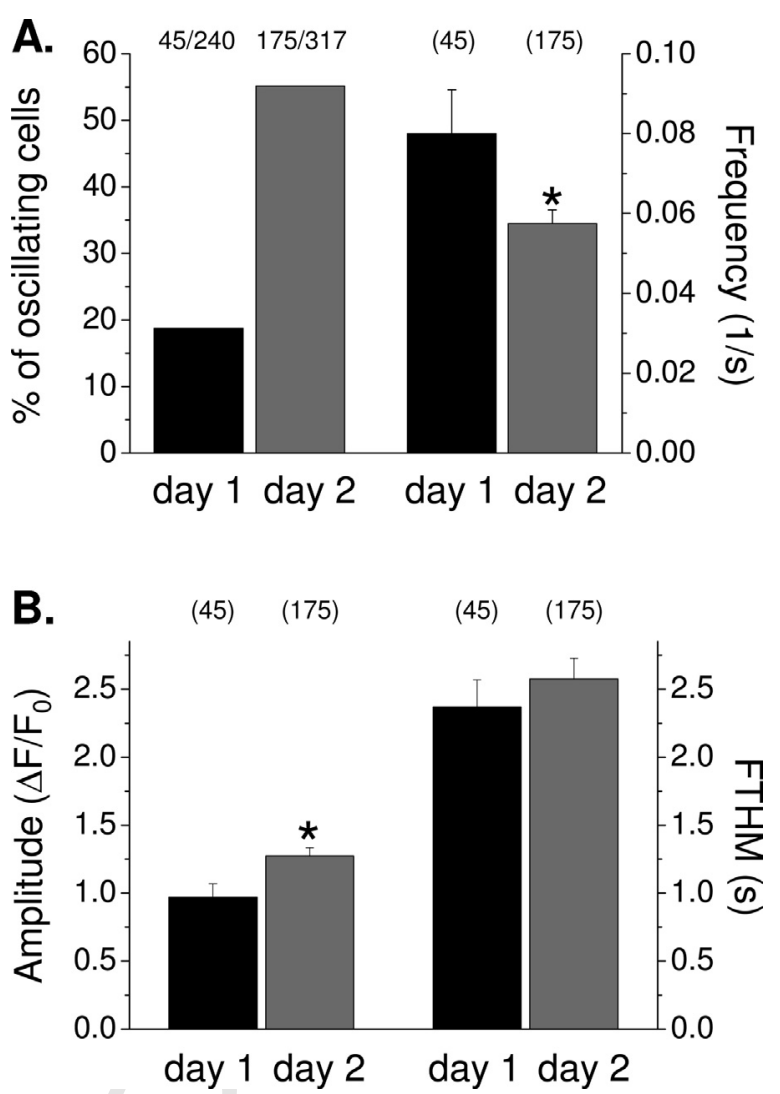

Fig. 2. Pooled data of $\mathrm{Ca}^{2+}$ oscillations gathered from series of $\mathrm{X}-\mathrm{Y}$ images acquired from random visual fields of Fluo-4 loaded HDC on culturing days 1 and 2 with Zeiss LIVE 5 Laser Scanning Confocal Microscope. (A) Ratio of oscillating cells and frequency of repetitive $\mathrm{Ca}^{2+}$ transients on days 1 and 2 of culturing. Numbers above bars indicate the number of oscillating cells compared to all cells recorded. (B) Amplitude and full time at half maximum (FTHM) of $\mathrm{Ca}^{2+}$ oscillations in differentiating cells of HDC on culturing days 1 and 2. For both panels (A) and (B), while calculating the parameters of $\mathrm{Ca}^{2+}$ oscillations, only oscillating cells with round, chondroblast-like morphology were considered. Measurements were carried out on cultures from 4 independent experiments. Data represent mean \pm standard error of the mean (SEM). Numbers in parentheses above bars indicate the number of cells measured. Asterisks $\left({ }^{*}\right)$ mark significant differences $\left({ }^{*} P<0.05\right)$ between parameters of oscillating cells in 1- and 2-day-old HDC.

of cells to show transient increases in cytosolic $\mathrm{Ca}^{2+}$ concentration was substantially higher (175 of 317 cells; 55\%) (Fig. 2A). Not only the proportion of oscillating cells, but also their parameters exhibited substantial changes during the course of differentiation (Fig. 2A and B). While the frequency of oscillations were found to be significantly smaller on day $2(0.06 \pm 0.003 \mathrm{~Hz} ; n=175) v s$. day 1 $(0.08 \pm 0.01 \mathrm{~Hz} ; n=45 ; P=0.01)$ (Fig. $2 \mathrm{~A})$, the average amplitude of transient increases in cytosolic $\mathrm{Ca}^{2+}$ concentration-related fluorescence ratio significantly increased from day 1 (expressed as $\Delta F / F_{0}$ : $0.97 \pm 0.11 ; n=45)$ to culturing day $2(1.27 \pm 0.06 ; n=175 ; P=0.03)$ (Fig. 2B). The third variable that was used to describe the duration of individual spontaneous transients (full time at half maximum; FTHM) did not prove to be statistically different on the two culturing days investigated $(2.37 \pm 0.29 \mathrm{~s} ; n=45$ on day $1 v s .2 .57 \pm 0.15 \mathrm{~s}$; $n=175$ on day $2 ; P=0.55$ ) (Fig. 2 B).

\subsection{Altered extracellular ionic milieu and $\mathrm{Ca}^{2+}$ entry blockers modify the appearance and quantitative parameters of rapid spontaneous $\mathrm{Ca}^{2+}$ oscillations in a time-dependent manner}

Parameters of spontaneous $\mathrm{Ca}^{2+}$ oscillations were examined on day 2 of culturing by recording series of $\mathrm{X}-\mathrm{Y}$ images. In each culture, a random visual field with oscillating cells was set, and frames 
were acquired in control conditions (normal Tyrode's solution; containing $1.8 \mathrm{mM} \mathrm{Ca}^{2+}$ ) at the 0 time point, and then in the presence of test solutions (either $10 \mu \mathrm{M}$ nifedipine; or $500 \mu \mathrm{M} \mathrm{LaCl}_{3}$ and $1 \mu \mathrm{M}$ YM-58483); 1,3 and $5 \mathrm{~min}$ after changing the bath to the test solutions. Control measurements were performed on random visual fields in cultures at $0-, 1-, 3$ - and 5-min time points in normal Tyrode's solution. It should be noted that all three parameters of $\mathrm{Ca}^{2+}$ oscillations investigated in this study (i.e. ratio of oscillating cells; amplitude and frequency of oscillations) followed a steady decline in the 5-min time frame even in control conditions; therefore, all parameters following an intervention were normalised to their respective control values (data not shown).

Application of the dihydropyridine L-type $\mathrm{Ca}^{2+}$ channel blocker nifedipine did not cause significant changes in the ratio of oscillating cells as compared to untreated control cells recorded at 3 - and 5 -min time points $(80.93 \pm 25.78 \%[P=0.56]$; and $91.73 \pm 28.95[P=0.84]$, respectively; $n=43$ for all time points; Fig. $3 \mathrm{~A}$ ), and no significant changes were observed in the amplitude either $(87.58 \pm 11.89 \%[P=0.5] ; 69.44 \pm 10.26 \%[P=0.16]$; and $75.83 \pm 6.26 \%[P=0.13]$ at $1-, 3$ - and 5-min time points; $n=25,16$ and 11, respectively; Fig. $3 \mathrm{~B})$. At the same time, nifedipine decreased the frequency $(53.97 \pm 8.52 \%[P=0.01]$; and $64.46 \pm 12.88 \%[P=0.15]$ at 3 - and 5 -min time points; $n=16$ and 11 , respectively; Fig. $3 \mathrm{C}$ ) of $\mathrm{Ca}^{2+}$ oscillations; this parameter was found to be significantly different from the control at the 3-min time point. These results indicate that nifedipine interfered with the frequency of oscillations, rather than the actual number of oscillating cells and the amplitude of the $\mathrm{Ca}^{2+}$ transients. In other words, treatment with nifedipine did not abolish repetitive $\mathrm{Ca}^{2+}$ transients, suggesting that VOCCs are not the primary, although important factors to mediate this phenomenon.

By contrast, administration of the SOCE blockers significantly decreased the ratio of oscillating cells at all three time points $(11.59 \pm 6.95 \%[P=0.0006] ; 23.05 \pm 13.58 \%[P=0.008]$; and $0.0 \%$ $[P=0.0]$ at $1-, 3$ - and 5-min time points, respectively; $n=29$ for all time points) compared to the control (Fig. 3A); in particular, no oscillating cells could be observed in random visual fields after $5 \mathrm{~min}$. At the same time, amplitudes of repetitive $\mathrm{Ca}^{2+}$ transients were also reduced $(45.35 \pm 7.53 \%[P=0.24]$; and $58.33 \pm 12.85 \%$ $[P=0.34]$ at 1 - and 3 -min time points; $n=2$ and 3 , respectively; Fig. 3B), and these blockers also decreased the frequency of oscillations at the 3 -min time point $(45.45 \pm 22.72 \%[P=0.13] ; n=3$; Fig. 3C).

Since these results suggest that $\mathrm{ER} \mathrm{Ca}^{2+}$ stores play a determining role in regulating repetitive $\mathrm{Ca}^{2+}$ transients in differentiating cells of HDC, we aimed to further analyse the effects of blockade of store-operated $\mathrm{Ca}^{2+}$ channels, as well as removal of free extracellular $\mathrm{Ca}^{2+}$ ions from the bath solution with a higher temporal resolution on line-scan diagrams. In these measurements, only round-shaped differentiating cells that exhibited prominent $\mathrm{Ca}^{2+}$ oscillations were included and other cells were disregarded. Linescan images of oscillating cells were recorded on day 2 of culturing in normal Tyrode's solution (Fig. 4A). In the 46 cells examined, the frequency and the amplitude of $\mathrm{Ca}^{2+}$ oscillations were found to be $0.08 \pm 0.007 \mathrm{~Hz}$ and $1.44 \pm 0.15$, respectively. Then, measurements were continued by changing the entire volume of the bath solution on the cultures to the test solutions. When $\mathrm{LaCl}_{3}$ and YM-58483 were applied to oscillating cells $(n=10), \mathrm{Ca}^{2+}$ oscillations were blocked, and a severe disturbance in cytosolic $\mathrm{Ca}^{2+}$ was observed: small-amplitude arrhythmic fluctuations in basal cytosolic $\mathrm{Ca}^{2+}$ concentration, rather than periodic $\mathrm{Ca}^{2+}$ transients, were recorded; therefore, the analysis of $\mathrm{Ca}^{2+}$ concentration-related changes in relative fluorescence intensities could not be performed (Fig. 4B). With the ER $\mathrm{Ca}^{2+}$ stores depleted-i.e. when the SERCA-blocker CPA was co-applied with $\mathrm{LaCl}_{3}$ and YM-58483-Ca ${ }^{2+}$ oscillations were immediately eliminated $(n=10)$ and no changes in cytosolic
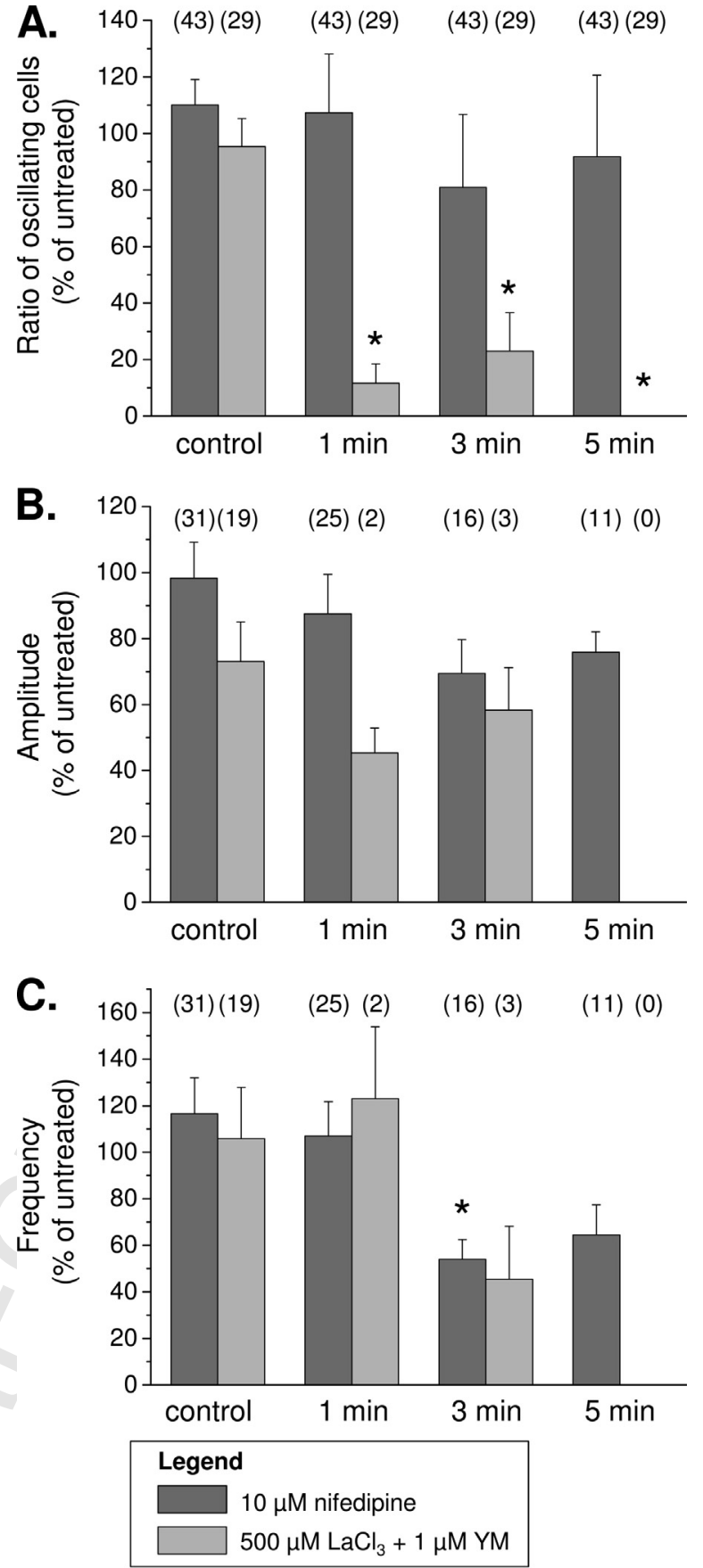

Fig. 3. Pooled data of $\mathrm{Ca}^{2+}$ oscillations obtained from series of $\mathrm{X}-\mathrm{Y}$ images acquired from Fluo-4 loaded HDC in response to various treatments. Measurements were carried out with Zeiss LIVE 5 Laser Scanning Confocal Microscope. A total number of 500 images were recorded at each time point for each visual field; frame acquisition rate was $10 \mathrm{~s}^{-1}$. (A) Percentage of oscillating cells before treatment (control), and 1,3 or $5 \mathrm{~min}$ after the application of bath solution containing $10 \mu \mathrm{M}$ nifedipine, or $500 \mu \mathrm{M} \mathrm{LaCl}_{3}$ and $1 \mu \mathrm{M}$ YM-58483. Values were normalised to the untreated cells measured at 0 min (control), and then at 1, 3 and 5 min. Numbers in parentheses above bars show the number of cells measured. (B) Amplitude of $\mathrm{Ca}^{2+}$ oscillations, normalised to values of untreated control cells. Numbers in parentheses above bars represent the number of oscillating cells measured.(C) Frequency of $\mathrm{Ca}^{2+}$ oscillations normalised to the control. Numbers in parentheses above bars show the number of cells measured. For panels (A)-(C), oscillating cells with round morphology in the same random visual field were recorded at all four time points. Differentiating cartilage colonies were only used for a single measurement series and then were discarded. Graphs represent pooled data of 3 independent experiments, measuring random visual fields of 5 colonies for each treatment. Asterisks $\left({ }^{*}\right)$ mark significant differences $\left({ }^{*} P<0.05\right)$ between parameters of treated $v s$. control cells at respective time points. 


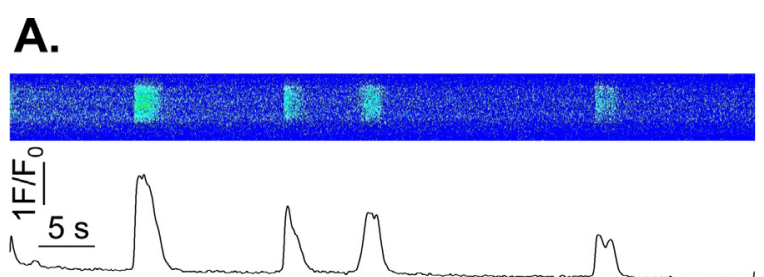

B.
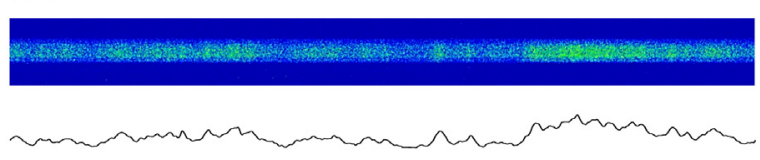

$500 \mu \mathrm{M} \mathrm{LaCl}{ }_{3}+1 \mu \mathrm{M} \mathrm{YM}\left(1.8 \mathrm{mM} \mathrm{Ca}^{2+}\right)$

C.

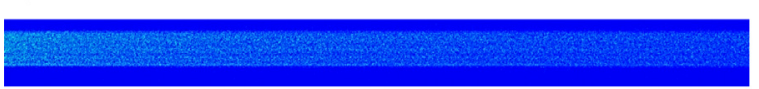

$500 \mu \mathrm{M} \mathrm{LaCl}_{3}+1 \mu \mathrm{M} \mathrm{YM}+10 \mu \mathrm{M} \mathrm{CPA}\left(1.8 \mathrm{mM} \mathrm{Ca}^{2+}\right)$

D.

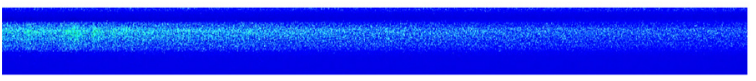

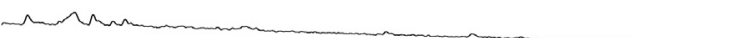

$0 \mathrm{mM} \mathrm{Ca}{ }^{2+}$

Fig. 4. Pharmacological modulation of spontaneous $\mathrm{Ca}^{2+}$ oscillations and effects of altered extracellular ionic milieu in Fluo-4 loaded differentiating chondrocytes of 2-day-old HDC. Representative confocal line-scan images and time courses of Fluo-4 fluorescence intensities are shown; horizontal and vertical calibrations are the same for all traces in panels (A)-(D). Horizontal lines under traces show the duration of treatments with pharmacons or altered extracellular ionic milieu. Acquisition of line-scan images started immediately after changing the bath solution on the cultures. Prior to that, normal functions were detected on each culture. (A) Spontaneous $\mathrm{Ca}^{2+}$ oscillations in normal $\left(\left[\mathrm{Ca}^{2+}\right]_{\mathrm{e}}=1.8 \mathrm{mM}\right)$ Tyrode's solution. (B) After the non-selective cation channel-mediated $\mathrm{Ca}^{2+}$ entry blocker $\mathrm{LaCl}_{3}(500 \mu \mathrm{M})$ and the store-operated $\mathrm{Ca}^{2+}$ entry and $\mathrm{Ca}^{2+}$ release-activated $\mathrm{Ca}^{2+}(\mathrm{CRAC})$ channel blocker YM-58483 $(1 \mu \mathrm{M})$ were applied in normal $\left(\left[\mathrm{Ca}^{2+}\right]_{\mathrm{e}}=1.8 \mathrm{mM}\right)$ Tyrode's, $\mathrm{Ca}^{2+}$ oscillations ceased, although irregular fluctuations in basal cytosolic $\mathrm{Ca}^{2+}$ concentration remained detectable. (C) When the SERCA-blocker CPA $(10 \mu \mathrm{M})$ was

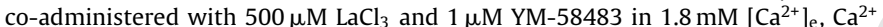
oscillations were totally eliminated. (D) 3 min after changing the bath solution to $\mathrm{Ca}^{2+}$-free Tyrode's, periodic oscillations could not be detected. Line-scan diagrams on panels (A)-(D) are representative data out of 4 independent experiments.

$\mathrm{Ca}^{2+}$ levels could be detected, even in the presence of external $\mathrm{Ca}^{2+}$ in the bath solution (Fig. $\left.4 \mathrm{C}\right)$. When oscillating cells $(n=10)$ were bathed with $\mathrm{Ca}^{2+}$-free Tyrode's solution, the amplitudes of oscillations gradually decreased, and only disappeared after several minutes. The representative line-scan diagram (Fig. 4D) shows lack of repetitive $\mathrm{Ca}^{2+}$ transients 3 min after changing the bath solution to $\mathrm{Ca}^{2+}$ free Tyrode's.

\subsection{Differentiating chondrocytes express the $\alpha_{1}$ subunit of VOCCS at both $m R N A$ and protein levels}

Since nifedipine was found to reduce the frequency of spontaneous $\mathrm{Ca}^{2+}$ oscillations; furthermore, application of $120 \mathrm{mM}$ $\mathrm{KCl}$ evoked large $\mathrm{Ca}^{2+}$ transients in the same experimental model in our previous experiments [21], we can hypothesise that voltage-operated $\mathrm{Ca}^{2+}$ channels may be expressed and function on differentiating chondrocytes. Of the several different subunits that comprise functional VOCCs, the $\mathrm{Ca}^{2+}$ selective pore-forming $\alpha_{1}$ subunit is the one that primarily determines the channel properties. Therefore, we first downloaded available sequence data for chicken $\alpha_{1}$ subunit mRNAs, and carried out RT-PCR reactions with primer pairs specific for each type of VOCC designed by Primer Premier 5.0 software (Premier Biosoft, Palo Alto, CA, USA). Two ion channel subunit mRNA transcripts $\left(\mathrm{Ca}_{\mathrm{V}} 1.2\right.$ and $\mathrm{Ca}_{\mathrm{V}}$ 1.3) of L-type (or dihydropyridine-sensitive) $\mathrm{Ca}^{2+}$ channels were found to be expressed by chondrocytes, with $\mathrm{Ca}_{\mathrm{V}} 1.2$ showing a constant expression level, while $\mathrm{Ca}_{\mathrm{V}} 1.3$ exhibited a peak-like pattern with almost 5-fold stronger signals on days 2-4 of culturing (Fig. 5A). By contrast, the R-type Cav $2.3 \alpha_{1}$ subunit mRNA showed a marked expression in chondroprogenitor mesenchymal cells, and gradually disappeared from differentiated chondroblasts and chondrocytes. The three T-type (Cav3.1, Cav3.2 and Cav3.3) ion channel subunits, interestingly, followed a very similar mRNA expression profile to what has been observed in case of L-type channels; $\mathrm{Ca}_{\mathrm{v}} 3.1$ and $\mathrm{Ca}_{\mathrm{v}} 3.2$ followed a constant expression (with the latter exhibiting signs of downregulation in mature chondrocytes), whereas $\mathrm{Ca}_{\mathrm{v}} 3.3$ also showed stronger signals during differentiation of chondroprogenitor cells on days 2-4 (Fig. 5A). Having confirmed mRNA expressions of various VOCCs, we also wanted to check the presence of $\alpha_{1}$ subunits at the protein level. By using a polyclonal antibody raised against $\mathrm{Ca}_{\mathrm{V}} \alpha_{1}$ subunits, immunoreactive bands were detected at the expected molecular weight (approx. $130 \mathrm{kDa}$ ). The protein showed strong expressions in total cell lysates of HDC throughout the entire culturing period (Fig. 5B). These findings, together with data obtained from $\mathrm{Ca}^{2+}$ imaging experiments, demonstrate the functional expression of various VOCCs in differentiating chondrogenic cells.

Next, we also undertook to characterise molecules that enable $\mathrm{Ca}^{2+}$ entry following store depletion (also known as $\mathrm{Ca}^{2+}$ releaseactivated $\mathrm{Ca}^{2+}$ or CRAC channels). Although Orai1 and STIM1, essential mediators of CRAC channel function, have been described in 2005 and 2006, respectively [27], their expression and function have not been investigated in chondrocytes. To this end, by designing specific primers, we were able to demonstrate the constant mRNA expression of STIM1, STIM2 and Orai1 throughout the entire culturing period (Fig. 5B), probably reflecting on their essential role in $\mathrm{Ca}^{2+}$ homeostasis. Furthermore, we also demonstrated the presence of STIM1 protein in total cell lysates of HDC on all culturing days, with a constant expression pattern (Fig. 5B). The identity of the upper immunogenic band at $\sim 90 \mathrm{kDa}$ is unknown; it can well be a glycosylated form or a splice variant of STIM1. Noteworthy that two STIM1 proteins of different size were found to be expressed in murine tissues: besides the well-known STIM1 isoform, a new $115 \mathrm{kDa}$ STIM1 referred to as STIM1L has also been recently reported [28]. Owing to lack of commercially available chicken-specific antibodies raised against Orai1, Western blot analysis of this protein could not be performed.

\subsection{Modulation of either VOCC function or SOCE in differentiating chondrocytes detrimentally affects in vitro chondrogenesis}

To assess the long-term effects of the dihydropyridine L-type $\mathrm{Ca}^{2+}$ channel blocker nifedipine (applied at $10 \mu \mathrm{M}$ continuously from day 1 , due to constant expression of $\alpha_{1}$ subunits) and SOCE inhibition combined with ER $\mathrm{Ca}^{2+}$ store depletion (by $500 \mu \mathrm{M}$ $\mathrm{LaCl}_{3}, 1 \mu \mathrm{M}$ YM-58483 and $10 \mu \mathrm{M} \mathrm{CPA}$ administered on day 2 for $24 \mathrm{~h}$ ) on cartilage matrix production in vitro, further experiments were performed. Continuous treatment with nifedipine significantly attenuated cartilage matrix production by culturing day 6 as revealed by metachromatic staining procedures (Fig. 6A). With $\mathrm{ER} \mathrm{Ca}^{2+}$ stores depleted, blockade of SOCE for only $24 \mathrm{~h}$ on day 2 resulted in an equally prominent inhibitory effect (Fig. 6A), reflecting on the important roles of both pathways (i.e. $\mathrm{Ca}^{2+}$ entry across the plasma membrane via VOCCs and $\mathrm{Ca}^{2+}$ release from internal $\mathrm{Ca}^{2+}$ stores) in $\mathrm{Ca}^{2+}$ homeostasis of differentiating chondrocytes. 
A.

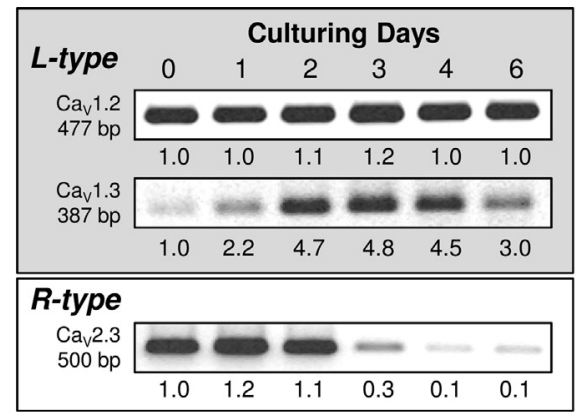

\begin{tabular}{|c|c|c|c|c|c|c|}
\hline \multicolumn{7}{|l|}{ T-type } \\
\hline \multirow{2}{*}{$\begin{array}{l}\mathrm{Ca}_{2} 3.1 \\
423 \mathrm{bp}\end{array}$} & - & 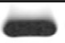 & 5 & b & 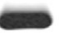 & 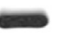 \\
\hline & 1.0 & 1.1 & 1.1 & 1.0 & 1.1 & 0.8 \\
\hline \multirow[t]{2}{*}{$\begin{array}{l}\mathrm{Ca}_{2} 3.2 \\
423 \mathrm{bp}\end{array}$} & $=$ & $=$ & $=$ & $=$ & $=$ & $=$ \\
\hline & 1.0 & 1.1 & 1.1 & 1.0 & 0.8 & 0.5 \\
\hline \multirow{2}{*}{$\begin{array}{l}\mathrm{Ca}_{3} 3.3 \\
437 \mathrm{bp}\end{array}$} & 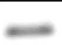 & - & 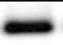 & & & \\
\hline & 1.0 & 1.4 & 2.7 & 3.8 & 3.9 & 2.5 \\
\hline
\end{tabular}

B.
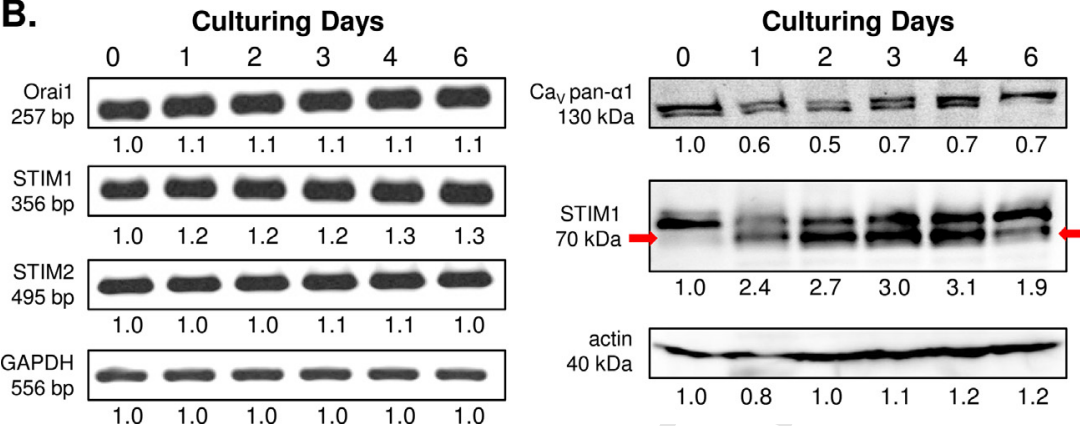

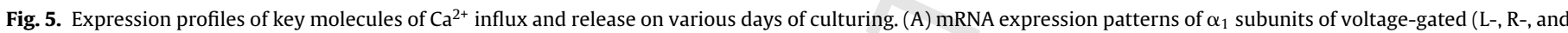

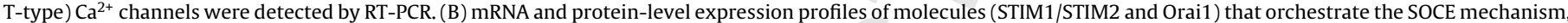

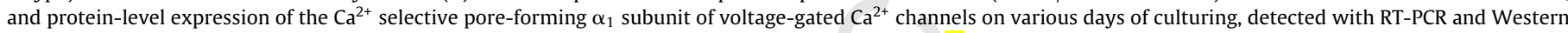

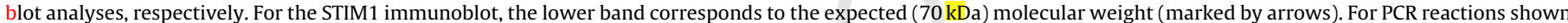

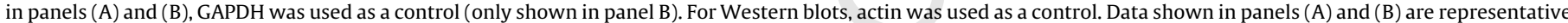

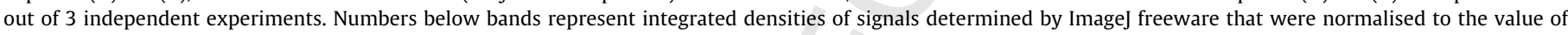
day 0 .

Noteworthy that combined treatments (with CPA, YM-58483 and $\mathrm{LaCl}_{3}$ ) longer than $24 \mathrm{~h}$ completely abrogated chondrogenesis (data not shown). Day 2 was chosen to assess the effects of SOCE inhibition on the differentiation step of chondroprogenitor cells.

Next, we looked at whether these treatments interfered with the mRNA and protein expression of key genes of chondrogenesis; as mRNA expression of type 2 collagen (COL2A1) and aggrecan core protein (AGR1), as well as mRNA and protein expression and phosphorylation status of the key chondrogenic marker Sox9 were monitored on culturing day 3 by RT-PCR and Western blot analyses, respectively. Although continuous treatment with nifedipine did not interfere with the mRNA expression of these genes, Sox9 protein expression was found to be markedly reduced, without a detectable change in its phosphorylation level (Fig. 6B and C). By contrast, interference to ER $\mathrm{Ca}^{2+}$ store functions caused a strong downregulation of mRNAs for ECM components, although mRNA transcript levels of Sox9 were not altered (Fig. 6B). At the protein level, Sox9 protein expression and phosphorylation status followed the same changes as observed for treatments with nifedipine; Sox9 protein level was also found to be decreased, and the phosphorylation status was also only slightly modified following SOCE block (Fig. 6C).

Since in addition to modulating in vitro chondrogenesis at the molecular level, these treatments could have altered metabolic activity and/or the cell cycle of differentiating chondrocytes; therefore, mitochondrial activity and rate of proliferation were also determined on day 3 by MTT test and ${ }^{3} \mathrm{H}$-thymidine incorporation assays, respectively. While neither nifedipine nor combined treatment to prevent $\mathrm{Ca}^{2+}$ re-uptake into depleted internal stores modulated cellular metabolic activity, both treatments almost completely abrogated cell proliferation (Fig. 6D). Consequently, the observed decrease in metachromatic matrix production can partially be attributed to the detected dramatic inhibition of cell proliferation.

\subsection{SOCE blockers alter the parameters of store-operated $\mathrm{Ca}^{2+}$ entry induced by store depletion during fluorescent single cell $\mathrm{Ca}^{2+}$ measurements}

Intracellular $\mathrm{Ca}^{2+}$ concentration measurements were performed in 2-day-old cultures loaded with Fura-2 to assess the parameters of $\mathrm{Ca}^{2+}$ transients triggered via SOCE in the absence (Fig. 7A) and in

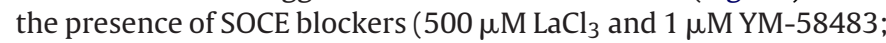
Fig. 7B). At the beginning of recordings, internal $\mathrm{Ca}^{2+}$ stores of cells were emptied by pre-treatment with the SERCA-inhibitor CPA $(10 \mu \mathrm{M})$ dissolved in $\mathrm{Ca}^{2+}$-free Tyrode's (not shown). The changes in cytosolic $\mathrm{Ca}^{2+}$ concentration evoked by re-establishing the normal (1.8 mM) extracellular $\mathrm{Ca}^{2+}$ concentration were then recorded. 
A.

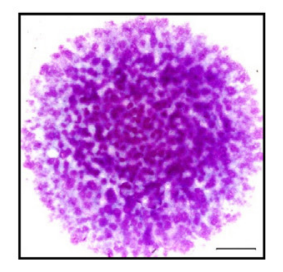

Control

$\left(\mathrm{OD}_{625}=100 \%\right)$

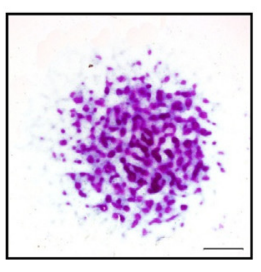

Nifedipine $10 \mu \mathrm{M}$

from day 1

$\left(\mathrm{OD}_{625}=10.4 \%{ }^{*}\right)$

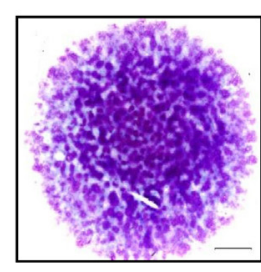

Control

$\left(\mathrm{OD}_{625}=100 \%\right)$

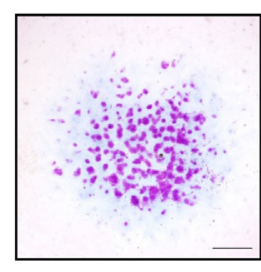

$\mathrm{LaCl}_{3}+\mathrm{YM}+\mathrm{CPA}$

$24 \mathrm{~h}$, day 2

$\left(\mathrm{OD}_{625}=19 \% \%^{*}\right)$

B.

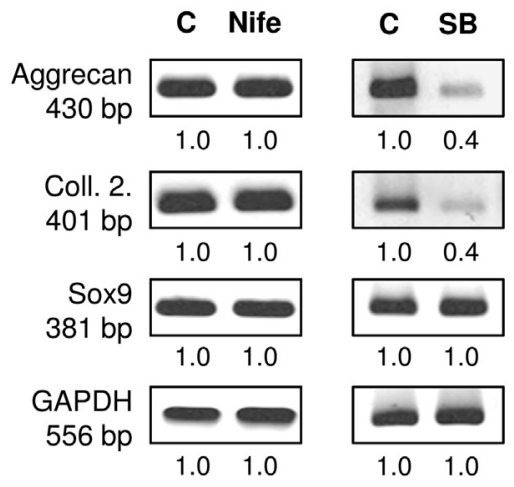

C.

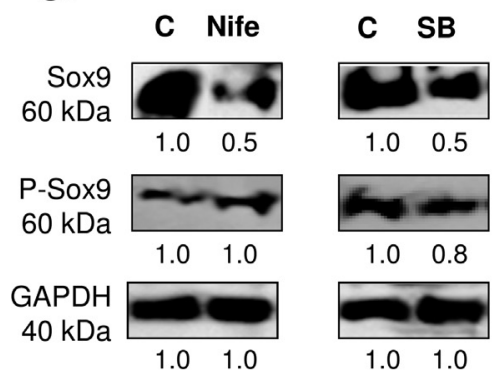

D.

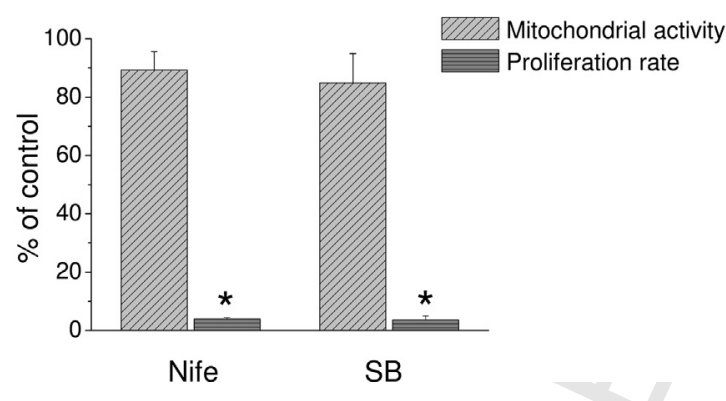

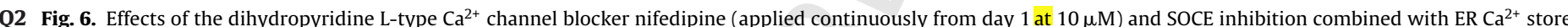

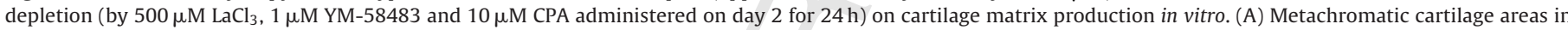

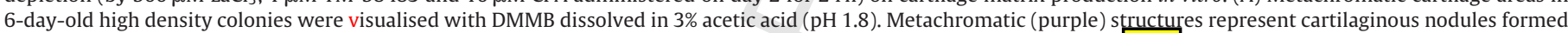

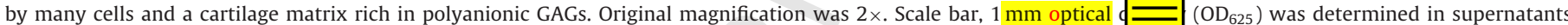

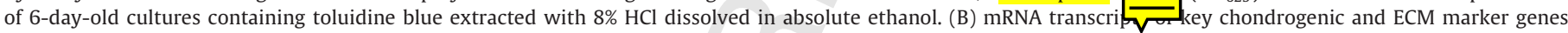

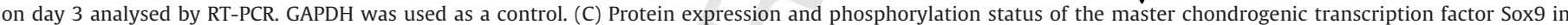

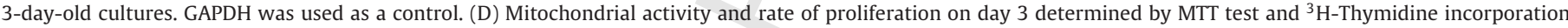

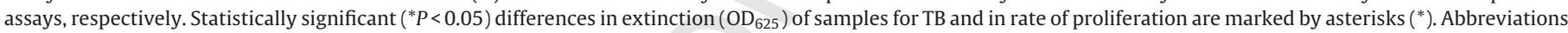

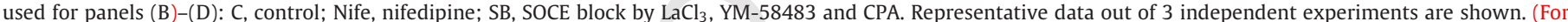
interpretation of the references to colour in this figure legend, the reader is referred to the web version of the article.)

Compared to untreated control cells, in the presence of the SOCE blockers both the amplitude (114.4 $\pm 15.6 ; n=16$ vs. $58.4 \pm 5.6$; $n=10 ; P=0.01 ;$ Fig. $7 C)$ and the maximal rate of rise $(3.9 \pm 0.5 ; n=16$ vs. $1.5 \pm 0.2 ; n=10 ; P=0.001$; Fig. 7D) of SOCE were significantly decreased.

\section{Discussion}

\section{1. $\mathrm{Ca}^{2+}$ homeostasis in differentiating chondrocytes}

It is generally accepted that $\mathrm{Ca}^{2+}$ is the most versatile second messenger. There is accumulating evidence that $\mathrm{Ca}^{2+}$ signalling pathways are key mediators of cellular events involved in differentiation processes also in non-excitable cells including MSCs and chondrocytes. A sustained rise in cytosolic $\mathrm{Ca}^{2+}$ concentration induces differentiation of MSCs: increased intracellular $\mathrm{Ca}^{2+}$ was reported to exert a biphasic regulatory role in adipocyte differentiation, inhibiting the early stages while promoting the late stage of differentiation [29]. Differentiation of mesenchymal cells into chondrocytes is also controlled by $\mathrm{Ca}^{2+}$ dependent pathways: high concentration of extracellular $\mathrm{Ca}^{2+}$ was found to promote chondrogenic differentiation in chicken HDC [30]. By contrast, extracellular $\mathrm{Ca}^{2+}$ was reported to modulate differentiation during skeletogenesis in chicken embryonic calvaria, where low concentrations enabled chondrogenesis [31]. The importance of $\mathrm{Ca}^{2+}$ influx via plasma membrane ion channels during chondrogenesis in mouse limb bud-derived HDC was confirmed by the fact that treatment with the L-type channel-specific blockers nifedipine and verapamil 
A.

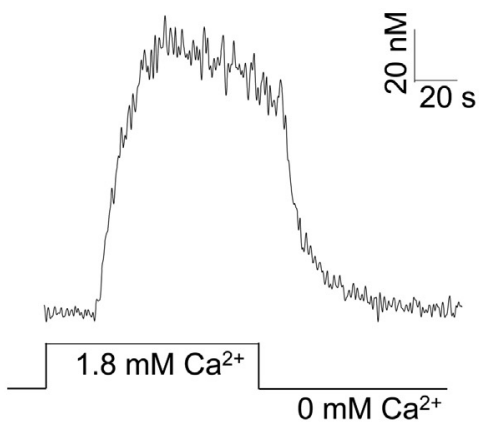

B.

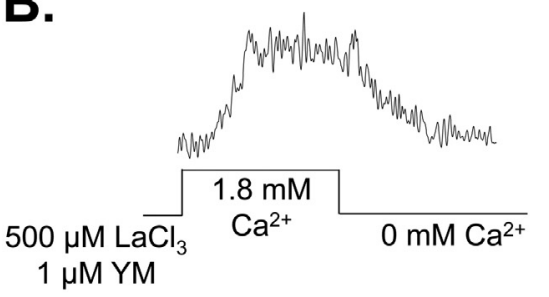

C.

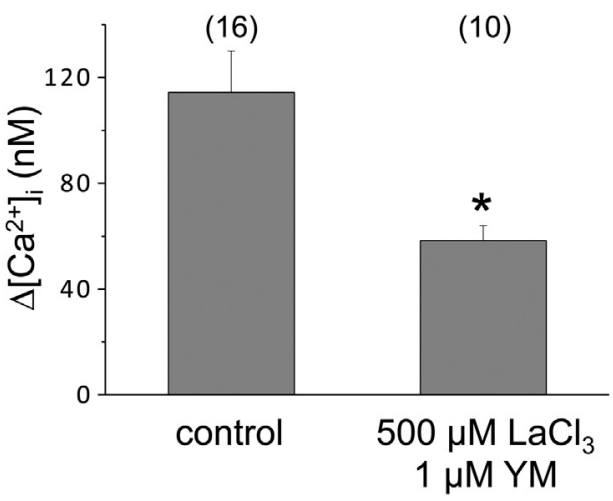

D.

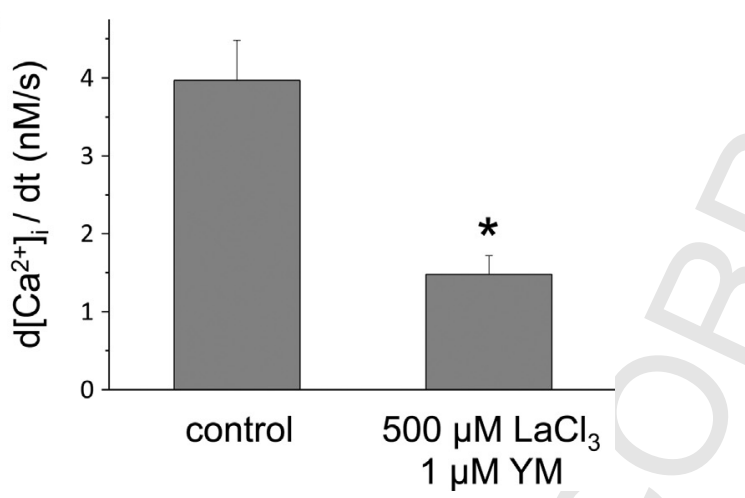

Fig. 7. Inhibition of store-operated $\mathrm{Ca}^{2+}$ entry (SOCE) in differentiating cells of Fura2 loaded 2-day-old HDC during single-cell fluorescent $\mathrm{Ca}^{2+}$ imaging. Internal $\mathrm{Ca}^{2+}$ stores of cells were previously depleted by the application of $10 \mu \mathrm{M} \mathrm{CPA} \mathrm{in} \mathrm{Ca}^{2+}$-free Tyrode's for $5 \mathrm{~min}$, which caused a marked decrease in $\left[\mathrm{Ca}^{2+}\right]_{\mathrm{i}}$ following a prominent increase (not shown). (A) When $\left[\mathrm{Ca}^{2+}\right]_{\mathrm{e}}$ was changed back to normal (1.8 mM), a large transient increase in $\left[\mathrm{Ca}^{2+}\right]_{i}$ was observed, demonstrating SOCE. (B) When SOCE was blocked by pre-treatment with $500 \mu \mathrm{M} \mathrm{LaCl}_{3}$ and $1 \mu \mathrm{M}$ YM-58483 for $5 \mathrm{~min}, \mathrm{Ca}^{2+}$ entry considerably decreased. (C) Pooled data of amplitudes of transients evoked by $\mathrm{Ca}^{2+}$ entry. (D) Mean values of the maximal rate of rise of SOCE (calculated as $\mathrm{d}\left[\mathrm{Ca}^{2+}\right]_{\mathrm{i}} / \mathrm{dt}$ ) after the re-administration of external calcium. Numbers in parentheses indicate the number of cells measured. Asterisks $\left({ }^{*}\right)$ mark significant $\left({ }^{*} \mathrm{P}<0.05\right)$ differences between control cultures and cells pre-treated with $\mathrm{LaCl}_{3}$ and YM-58483. Traces in panels (A) and (B) are representative out of 16 and 11 records, respectively. attenuated differentiation [32]. Consistent with the above findings, a sustained rise in cytosolic free $\mathrm{Ca}^{2+}$ concentration was found to coincide with the final commitment of differentiating chondroprogenitor cells in chicken HDC and proved to be a prerequisite to chondrogenic differentiation in these cultures [6].

\subsubsection{VOCCs mediate $\mathrm{Ca}^{2+}$ influx during chondrogenesis}

The above results concerning $\mathrm{Ca}^{2+}$ homeostasis and $\mathrm{Ca}^{2+}$ dependent signalling events during chondrogenesis suggest that chondrogenic differentiation partially depends on the availability of extracellular $\mathrm{Ca}^{2+}$ and that their influx via plasma membrane $\mathrm{Ca}^{2+}$ channels is indispensable. Indeed, many $\mathrm{Ca}^{2+}$ entry pathways have been identified in developing and mature chondrocytes by our laboratory and others, including P2X and P2Y purinergic receptors, $N$-methyl-D-aspartate receptor (NMDA) subunits, transient receptor potential (TRP) channels and arachidonate-regulated $\mathrm{Ca}^{2+}$-sensitive (ARC) channels [22]. NMDA receptors and TRPV ion channels are of particular importance since they are key mediators of biomechanical signals and are thus significant components of chondrocyte mechanotransduction pathways [33,34]. Besides these ligand-gated $\mathrm{Ca}^{2+}$ entry pathways, the functional expression of voltage-operated $\mathrm{Ca}^{2+}$ channels (VOCCs) has also been reported during chondrogenesis. VOCCs are large complexes consisting of several subunits $\left(\alpha_{1}, \alpha_{2} \delta, \beta_{1-4}\right.$, and $\left.\gamma\right)$, of which the $\alpha_{1}$ subunit determines their type, i.e. L- ( $\left.\mathrm{Ca}_{\mathrm{V}} 1.1,1.2,1.3,1.4\right)$, P/Q- $\left(\mathrm{Ca}_{\mathrm{V}} 2.1\right)$, $\mathrm{N}-\left(\mathrm{Ca}_{\mathrm{V}} 2.2\right), \mathrm{R}-\left(\mathrm{Ca}_{\mathrm{V}} 2.3\right)$ and T-type $\left(\mathrm{Ca}_{\mathrm{V}} 3.1,3.2,3.3\right) \mathrm{Ca}^{2+}$ channels [35]. Voltage-gated $\mathrm{Ca}^{2+}$ channels have long been known to be expressed by articular chondrocytes and contribute to elevation of cytosolic $\mathrm{Ca}^{2+}$ concentration via signalling through insulin-like growth factor-1 [36]. VOCCs were reported to co-localise with beta- 1 integrin, $\mathrm{Na}^{+} / \mathrm{K}^{+}$-ATPase and epithelial sodium channels in mechanoreceptor complexes in developing chondrocytes [37]; furthermore, expressions of $\mathrm{Ca}_{\mathrm{v}} 1.2$ and $\mathrm{Ca}_{\mathrm{v}} 3.2$ channel subunits were detected in chondrocytes derived from developing mouse embryos by immunohistochemical staining procedures and in the murine chondrogenic cell line ATDC5 [38]. Xu et al. recently demonstrated that $\mathrm{Ca}^{2+}$ influx via VOCCs is also necessary for signalling pathways in stimulated articular chondrocytes [39].

However, a detailed molecular characterisation of various VOCCs expressed in differentiating chondrogenic cells was lacking. Preliminary findings of our laboratory have implicated the involvement of various voltage-gated $\mathrm{Ca}^{2+}$ channels during in vitro chondrogenesis in chicken HDC as exposure to high concentrations of extracellular $\mathrm{K}^{+}$evoked large $\mathrm{Ca}^{2+}$ transients [21]. Therefore, we undertook to provide a detailed analysis of mRNA expression profiles of $\alpha_{1}$ subunits and found mRNA transcripts of two L-type ( $\mathrm{Ca}_{\mathrm{V}} 1.2$ and $\left.\mathrm{Ca} \mathrm{V}_{\mathrm{V}} 1.3\right)$, an R-type ( $\left.\mathrm{Ca}_{\mathrm{V}} 2.3\right)$ and all three T-type ( $\mathrm{Ca} \mathrm{V}_{\mathrm{V}} 3.1$, $\mathrm{Ca}_{\mathrm{v}} 3.2$ and $\left.\mathrm{Ca}_{\mathrm{v}} 3.3\right) \mathrm{Ca}^{2+}$ channels. Furthermore, we also confirmed the presence of $\alpha_{1}$ subunit proteins in total cell lysates throughout the entire culturing period, suggesting that VOCCs may play a role during the differentiation of chondroprogenitor cells to chondroblasts and mature chondrocytes. The presence of the $\alpha_{1}$ subunit in chondrocytes was first confirmed by Shakibaei and Mobasheri in 2003 [37]. Since then, $\mathrm{Ca}^{2+}$ channel expression in chondrocytes has been implied also by others and suggested that they are involved in mechanotransduction pathways [40]. Furthermore, both differentiating hMSCs and limb bud-derived chondroprogenitor mesenchymal cells were found to express L- and T-type $\mathrm{Ca}^{2+}$ channels, which probably reflects on the role of these specific channels in controlling $\mathrm{Ca}^{2+}$ homeostasis during differentiation. Although the molecular and functional characterisation of VOCCs during osteogenic differentiation of hMSCs has been published [41], this is the first study to provide a comprehensive analysis of VOCC expression during in vitro chondrogenesis.

As far as the function of VOCCs during regulation of chondrogenesis is concerned, when the L-type channel specific inhibitor 
nifedipine was administered to differentiating HDC from day 1, a markedly reduced cartilage ECM production was detected by the end of the 6-day-long culturing period. Consistent with this, Sox9 protein expression was considerably attenuated. These findings are in a good correlation with results gained earlier on mouse embryonic limb bud mesenchymal cells, where chondrogenesis was inhibited by continuous application of nifedipine [32]. By contrast, nifedipine did not interfere with osteogenic differentiation of hMSCs [41]. However, this contradiction may be resolved if one hypothesises that the $\mathrm{Ca}^{2+}$-dependent molecular machinery that regulates osteo- and chondrogenesis may be different; moreover, differentiation steps of adult bone marrow MSCs (which are multipotent and give rise to many cell types) and embryonic chondroprogenitor mesenchymal cells (that are already committed towards the chondrogenic lineage) may also utilise different regulatory pathways.

VOCCs (in particular, L- and T-type) have long been known to regulate cell proliferation [42]. The concept that the control of the cell cycle is at least partially $\mathrm{Ca}^{2+}$ dependent has been proposed some 40 years ago but this field is still controversial. Both $\mathrm{Ca}^{2+}$ influx from extracellular space and $\mathrm{Ca}^{2+}$ release from internal stores were reported to govern cell proliferation; the dependence of progression through cell cycle on $\mathrm{Ca}^{2+}$ influx may rely on $\mathrm{ER} \mathrm{Ca}^{2+}$ contents as it substantially varies from one cell type to another [43]. Of the plasma membrane $\mathrm{Ca}^{2+}$ ion channels, VOCCs (especially T-type channels) may play a determining role in cell cycle regulation in non-excitable cells by allowing for a constitutive $\mathrm{Ca}^{2+}$ influx that is very sensitive even to modest changes in resting membrane potential (RMP) owing to their unique low voltage-dependent activation/inactivation and slow deactivation properties [43]. Noteworthy that cells of chondrifying HDC were found to express all three T-type channel mRNAs throughout the entire culturing period in this study, probably reflecting on the important role of these VOCCs in $\mathrm{Ca}^{2+}$ homeostasis during chondrogenesis. Since in vitro chondrogenesis requires high cellular density, block of voltage-operated $\mathrm{Ca}^{2+}$ channels could have interfered with chondrogenic differentiation of HDC by inhibiting cellular proliferation. Indeed, application of the Ltype channel blocker nifedipine exerted antiproliferative effects in differentiating chondrocytes as it was revealed by monitoring the rate of DNA synthesis. Therefore VOCCs, besides mediating long-lasting $\mathrm{Ca}^{2+}$ influx and maintaining basal cytosolic $\mathrm{Ca}^{2+}$ levels, may be important regulators of cell division required for condensation of mesenchymal cells prior to chondrogenic differentiation in response to changes of RMP brought about by e.g. voltagedependent $\mathrm{K}^{+}$channels (such as $\mathrm{K}_{\mathrm{V}} 1.1$ and $\mathrm{K}_{\mathrm{V}} 1.3$ ) also expressed by cells of HDC [21].

\subsubsection{STIM1/STIM2 and Orai1 mediate store-operated $\mathrm{Ca}^{2+}$ entry (SOCE) in differentiating chondrocytes}

In addition to $\mathrm{Ca}^{2+}$ entry across the plasma membrane mediated by either voltage or ligand gated ion channels, a further source of transient increases of cytosolic $\mathrm{Ca}^{2+}$ concentration is $\mathrm{Ca}^{2+}$ release from the $\mathrm{ER} \mathrm{Ca}^{2+}$ stores via $\mathrm{Ca}^{2+}$ permeable $\mathrm{IP}_{3} \mathrm{R}$ or RyR channels [44]. $\mathrm{Ca}^{2+}$ content of internal pools primarily depends on $\mathrm{Ca}^{2+}$ uptake through SERCA and/or $\mathrm{Na}^{+}-\mathrm{Ca}^{2+}$ exchanger (NCX), buffering capacity of ER $\mathrm{Ca}^{2+}$ binding proteins, and $\mathrm{Ca}^{2+}$ release. Non-excitable cells preferentially utilise pathways that trigger the activation of $\mathrm{IP}_{3} \mathrm{Rs}$, rather than $\mathrm{Ca}^{2+}$ release via RyR [45]. In fact, administration of caffeine, a strong agonist that activates RyR had no effect either in mature [46] or in differentiating chondrocytes [6], which is consistent with what has been observed in human and murine mesenchymal and embryonic stem cells $[5,47]$. Furthermore, while $\mathrm{IP}_{3} \mathrm{R}$ mRNA and protein expression was demonstrated in differentiating chondrocytes (and also in human MSCs), no mRNA transcripts for RyR were detectable either in
MSCs or in cells of HDC [5,6]. Given that the ER $\mathrm{Ca}^{2+}$ stores in non-excitable cells including chondrocytes are relatively small, signalling pathways that generate the lipid metabolite $\mathrm{IP}_{3}$, which triggers $\mathrm{Ca}^{2+}$ release via $\mathrm{IP}_{3} \mathrm{Rs}$ may lead to store depletion. This, in turn, activates $\mathrm{Ca}^{2+}$ entry across the plasma membrane, a process termed store-operated $\mathrm{Ca}^{2+}$ entry (SOCE), accomplished by the activation of CRAC channels to refill the ER stores [44]. SOCE has been shown to contribute to maintenance of $\mathrm{Ca}^{2+}$ homeostasis in many non-excitable cells including both rat primary chondrocytes [48] and in the human chondrosarcoma cell line OUMS-27 [49]; furthermore, we also demonstrated earlier that upon store depletion brought about by preventing $\mathrm{Ca}^{2+}$ re-uptake into the ER using the SERCA pump inhibitor CPA, differentiating chondrocytes exhibited large transient rise in cytosolic $\mathrm{Ca}^{2+}$ concentration when extracellular $\mathrm{Ca}^{2+}$ became available [6]. However, CRAC channels and molecules involved in SOCE in either mature or developing chondrocytes have not been extensively characterised.

SOCE is a complex series of events initiated by oligomerisation of the $\mathrm{Ca}^{2+}$ sensor stromal interaction molecule (STIM1) and STIM2 in the ER membrane triggered by a decrease in ER $\mathrm{Ca}^{2+}$ content below a certain threshold. Oligomerisation of STIM1/STIM2 is followed by redistribution into distinct puncta in the ER membrane that are located in close proximity to the plasma membrane, where STIM directly interacts with Orai1 dimers to form tetramers, thus giving rise to the functional CRAC channel [27].

Chondrocytes have long been known to possess releasable ER $\mathrm{Ca}^{2+}$ stores [50]; furthermore, as mentioned above, our laboratory has also demonstrated releasable $\mathrm{Ca}^{2+}$ stores in cells of differentiating cartilage [6]. However, the detailed characterisation of $\mathrm{Ca}^{2+}$ transients induced by SOCE was lacking. This is the first study to provide direct evidence on the functional expression of the molecules that mediate SOCE in differentiating chondrocytes. mRNA transcripts of Orai1, as well as STIM1 and STIM2 were found to be expressed in cells of HDC at constant levels throughout the entire culturing period. Furthermore, STIM1 expression at the protein level has also been confirmed. STIM2 may also have important functions in developing chondrocytes as it is activated by smaller decreases in ER $\mathrm{Ca}^{2+}$ concentrations than STIM1 and therefore it has been proposed to regulate basal cytosolic $\mathrm{Ca}^{2+}$ concentrations [51]. Owing to species limitations (lack of commercially available antisera raised against chicken Orai1) we were unable to demonstrate the presence of the Orai1 protein. Nevertheless, the fact that store-operated $\mathrm{Ca}^{2+}$ entry was recorded in cells of HDC during single cell fluorescent $\mathrm{Ca}^{2+}$ measurements provides indirect evidence on the protein expression of the poreforming subunit of CRAC channels. Furthermore, SOCE mediated by interaction between STIM and Orai1 seems to be a very important contributor to normal $\mathrm{Ca}^{2+}$ homeostasis of differentiating chondrocytes as blockade of SOCE combined with ER $\mathrm{Ca}^{2+}$ store depletion by preventing re-uptake with continuous application of CPA almost completely abrogated in vitro chondrogenesis. Insufficient replenishment of ER $\mathrm{Ca}^{2+}$ stores and consequently disturbed $\mathrm{Ca}^{2+}$ homeostasis may modulate cartilage formation by detrimentally affecting cell division. Indeed, proliferation rate in cells with depleted internal $\mathrm{Ca}^{2+}$ stores was found to be almost completely attenuated, without severely affecting mitochondrial metabolic activity. These results further support the concept that the cell proliferation machinery in differentiating chondrocytes is very sensitive to changes in cytosolic $\mathrm{Ca}^{2+}$ levels, irrespective of the source of $\mathrm{Ca}^{2+}$ (either $\mathrm{Ca}^{2+}$ entry across the plasma membrane or $\mathrm{Ca}^{2+}$ release from internal stores); notwithstanding the fact that the relationship between ER $\mathrm{Ca}^{2+}$ contents and cell cycle regulation is controversial and seems to be cell type-specific as discussed by Capiod [43]. 


\subsection{Possible role of $\mathrm{Ca}^{2+}$ oscillations during chondrogenesis}

Many studies have shown that the frequency of biological oscillations encode dynamical information to control varied cellular activities including gene activation, cell division, or proliferation. In particular, periodic $\mathrm{Ca}^{2+}$ oscillations are generally accepted to enhance efficiency and specificity of signalling pathways at lower levels of stimulation than a small, sustained increase in basal $\mathrm{Ca}^{2+}$ levels [52]. Therefore, $\mathrm{Ca}^{2+}$ oscillations are considered to be more suitable for cells that only receive low levels of stimulation and/or characterised by low receptor occupancies. It is therefore not surprising that periodic fluctuations in basal cytosolic $\mathrm{Ca}^{2+}$ concentration have been observed in many non-excitable cells including MSCs and chondrocytes.

The concept of an intracellular "pulsatile $\mathrm{Ca}^{2+}$ pacemaker" region that is capable of initiating and maintaining rhythmic $\mathrm{Ca}^{2+}$ oscillations in isolated articular chondrocytes was first proposed by D'Andrea and Vittur in 1995 [50]. Later on, others have also reported on spontaneous $\mathrm{Ca}^{2+}$ oscillations in sliced cartilage and primary chondrocyte cultures; furthermore, mechanically induced $\mathrm{Ca}^{2+}$ waves regulated by a paracrine purinergic signalling pathway have also been described [53]. This is particularly important as $\mathrm{Ca}^{2+}$ oscillations and consequent activation of NFAT that governs proliferation and differentiation were also found to be regulated by an ATP autocrine/paracrine loop in human MSCs [54]. Interestingly, however, in the murine chondrogenic teratocarcinoma cell line ATDC5, $\mathrm{Ca}^{2+}$ oscillations were found to drive ATP oscillations that play a critical role during prechondrogenic condensation and oscillatory secretion of ECM and cell adhesion molecules [55]. Furthermore, the same laboratory has proposed that these $\mathrm{Ca}^{2+}$-driven ATP oscillations are initiated by extracellular ATP signalling via the ionotropic purinergic receptor $\mathrm{P}_{2} \mathrm{X}_{4}$ [56]; the same receptor that was suggested by our laboratory to be a key player in mediating $\mathrm{Ca}^{2+}$ influx in differentiating chondrocytes [20]. Nevertheless, a reciprocal regulatory loop between ATP and $\mathrm{Ca}^{2+}$ oscillations in differentiating MSCs and chondrocytes can be hypothesised that may drive differentiation and/or proliferation of these cell types.

As far as temporal aspects of $\mathrm{Ca}^{2+}$ oscillations in non-excitable cells are concerned, huge variations exist. For MSCs, the average period of cyclic $\mathrm{Ca}^{2+}$ transients was $5.7 \pm 3.0 \mathrm{~min}$ [5] with large individual variability. Cells in primary cultures of human osteoblasts were also reported to exhibit spontaneous oscillations with a frequency of $0.25-0.6 \mathrm{~min}^{-1}$ [57], which correlates well with the range observed in MSCs. In chondrocytes, however, oscillations exhibited greater variability. In a slice of mature rabbit articular cartilage, individual chondrocytes exhibited spontaneous long-lasting (up to 30 s) $\mathrm{Ca}^{2+}$ transients within a 120 -s-long observation period [53]. Cytosolic $\mathrm{Ca}^{2+}$ (and subsequently ATP) in the chondrogenic ATDC5 cell line were found to oscillate with a period of 1 transient in approx. every $6 \mathrm{~h}$ [55]. By contrast, our measurements performed on differentiating cells of chicken micromass cultures revealed spontaneous $\mathrm{Ca}^{2+}$ oscillations at a significantly higher frequency. In 45 of 240 cells (19\%) and in 175 of 317 cells (55\%) examined during this study on culturing days 1 and 2, respectively, Fluo-4-loaded cells in HDC exhibited cyclic $\mathrm{Ca}^{2+}$ transients at a rate of $0.08 \pm 0.01 \mathrm{~Hz}$ on day 1 , which decreased to $0.06 \pm 0.003 \mathrm{~Hz}$ by culturing day 2 . In a recent study performed by Nguyen et al., Fluo-4 loaded bovine articular chondrocytes were found to exhibit oscillations at a comparably high frequency to cells of HDC; furthermore, these oscillations were also dependent on both extracellular and intracellular $\mathrm{Ca}^{2+}$ sources, as well as relied on the function of voltage-dependent and voltage-independent $\mathrm{Ca}^{2+}$ channels [58]. However, in this work, oscillations were induced by basic calcium phosphate (BCP) crystals to mimic microcrystalline stress, a phenomenon involved in OA pathogenesis; moreover, the authors concluded that $\mathrm{BCP}$ crystal-induced $\mathrm{Ca}^{2+}$ oscillations were deleterious as they were involved in proteoglycan degradation. By contrast, spontaneous $\mathrm{Ca}^{2+}$ transients in limb bud-derived chondrifying cultures seemed to be inherent features of differentiating cells of HDC.

\subsection{Involvement of $\mathrm{Ca}^{2+}$ entry and release processes in $\mathrm{Ca}^{2+}$ oscillations}

Although we have investigated the source of $\mathrm{Ca}^{2+}$ flux that generates transient increases in cytosolic $\mathrm{Ca}^{2+}$ in a previous study [21], we now performed a more thorough analysis. We found that lack of free $\mathrm{Ca}^{2+}$ in the bath solution abrogated oscillations after a few minutes; this implies the dependence of the phenomenon on $\mathrm{Ca}^{2+}$ entry across the plasma membrane, and at the same time provides evidence that internal stores also contribute to the maintenance of oscillations, but only to a limited extent, probably owing to their relatively low $\mathrm{Ca}^{2+}$ contents. This finding is in accordance with what has been described in hMSCs, since this group has also concluded that $\mathrm{Ca}^{2+}$ entry was required to sustain $\mathrm{Ca}^{2+}$ oscillations [5]. Similar results were observed also in differentiating human osteoblast-like cells [57]. To identify $\mathrm{Ca}^{2+}$ channels that maintain $\mathrm{Ca}^{2+}$ entry during periodic transients, we examined whether VOCCs that proved to be important regulators of sustained $\mathrm{Ca}^{2+}$ transport across the plasma membrane were involved in this process. When the L-type $\mathrm{Ca}^{2+}$ channel blocker nifedipine was applied during fluorescent $\mathrm{Ca}^{2+}$ imaging, it slightly reduced the ratio of oscillating cells, as well as parameters (amplitude and frequency) of $\mathrm{Ca}^{2+}$ oscillations compared to untreated controls. These results indicate that $\mathrm{Ca}^{2+}$ influx via VOCCs indeed plays a role in maintaining $\mathrm{Ca}^{2+}$ oscillations, but their contribution is only secondary. By contrast, application of nifedipine on osteoblasts had no effect on $\mathrm{Ca}^{2+}$ oscillations [57].

Next, we looked at the role of internal $\mathrm{Ca}^{2+}$ stores. When $\mathrm{LaCl}_{3}$ and YM-58483, blockers that inhibit all channel-mediated $\mathrm{Ca}^{2+}$ entry and CRAC channels, respectively, were applied to oscillating cells, a severe disturbance in cytosolic $\mathrm{Ca}^{2+}$ was observed: small-amplitude fluctuations, rather than periodic $\mathrm{Ca}^{2+}$ transients,

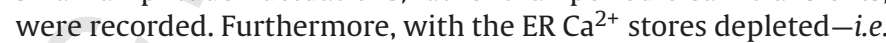
when the SERCA-blocker CPA was co-applied with $\mathrm{LaCl}_{3}$ and YM58483 - no changes in cytosolic $\mathrm{Ca}^{2+}$ levels could be detected, even in the presence of external $\mathrm{Ca}^{2+}$ in the bath solution. Therefore, $\mathrm{Ca}^{2+}$ cycling between intracellular pools and the cytosol seems to be a determining factor in the generation of spontaneous $\mathrm{Ca}^{2+}$ transients as blockade of SOCE combined with store depletion completely abrogated oscillations. These results are in a complete agreement with what has been observed in osteoblasts where oscillations could also be blocked by store depletion induced with thapsigargin [57]. Since Kawano et al. have also reported on the dependence of spontaneous $\mathrm{Ca}^{2+}$ oscillations on internal $\mathrm{Ca}^{2+}$ pools in hMSCs [5], the determining role of $\mathrm{ER} \mathrm{Ca}^{2+}$ stores and processes of store replenishment (SOCE; including STIM and Orai isoforms) in the generation/maintenance of $\mathrm{Ca}^{2+}$ oscillations seems to be a general phenomenon in differentiating mesenchymal cells.

\subsection{Molecular decoders of $\mathrm{Ca}^{2+}$ oscillations}

It is widely accepted that $\mathrm{Ca}^{2+}$ acts via activation of pathways that involve $\mathrm{Ca}^{2+}$-dependent protein kinases (classic PKCs, e.g. PKCalpha) and phosphoprotein phosphatases (calcineurin); these in turn trigger various transcription factors such as NFAT, NF- $\kappa B$, JNK1, MEF2 and CREB, depending on the frequency and amplitude of the $\mathrm{Ca}^{2+}$ transients. In lymphocytes and MSCs, $\mathrm{Ca}^{2+}$ oscillations were reported to trigger the calcineurin-dependent dephosphorylation and consequent nuclear translocation of NFAT [54]. The importance of the calcineurin-NFAT4 pathway has been demonstrated in chondrogenesis $[59,60]$. These data indicate that NFAT4 activation induced by high-frequency $\mathrm{Ca}^{2+}$ oscillations may play 


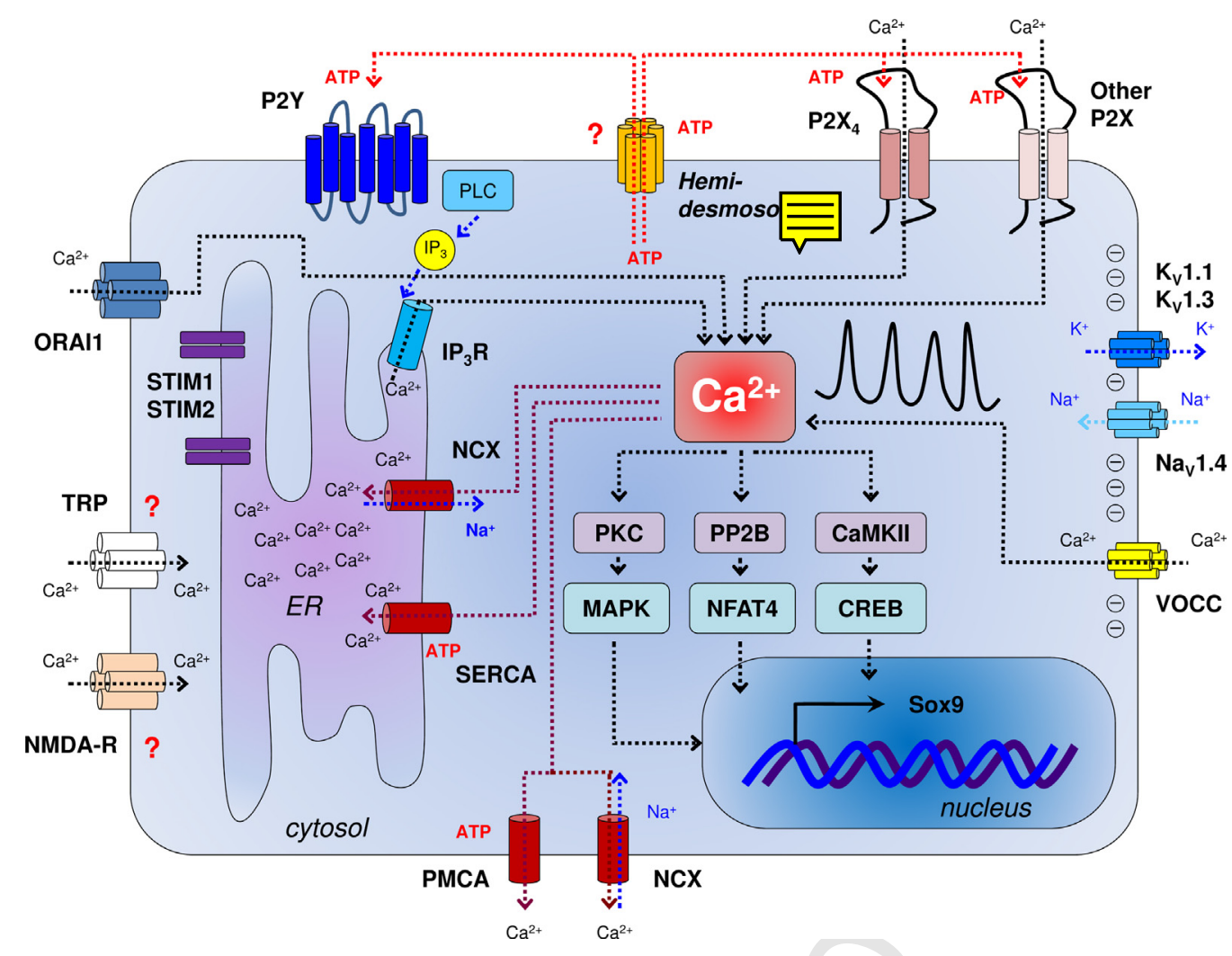

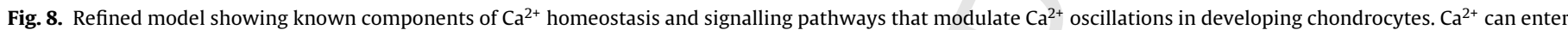

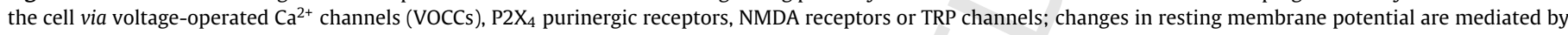

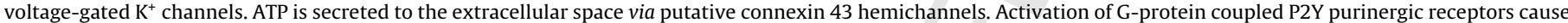

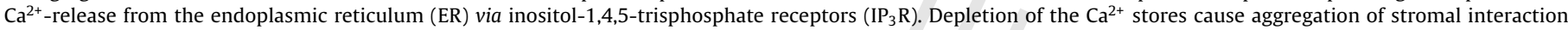

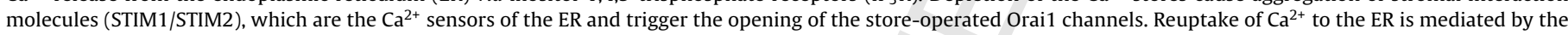
sarcoplasmic/endoplasmic reticulum $\mathrm{Ca}^{2+}$-ATPase (SERCA) and the $\mathrm{Na}^{+}-\mathrm{Ca}^{2+}$ exchanger (NCX). See text for details.

The concept of the image was adopted from [44].

important roles in regulating proliferation and differentiation during chondrogenesis.

Cyclic rise in basal cytosolic $\mathrm{Ca}^{2+}$ concentration may also trigger the activation of $\mathrm{Ca}^{2+}$-calmodulin dependent protein kinase II (CaMKII) that has been reported to act as a decoder of $\mathrm{Ca}^{2+}$ oscillations [61], owing to its complex regulation and progressive activation. CaMKII mediates many cellular functions in response to elevated $\mathrm{Ca}^{2+}$ in various cells and tissues, including regulation of ion channels, cytoskeleton, gene transcription and proliferation. Expression of various CaMKII enzymes has been confirmed in human articular chondrocytes at both mRNA and protein levels [62]; furthermore, we have also detected mRNA transcripts of CaMKII isoforms alpha, beta, gamma and delta in differentiating cells in HDC with variable expression patterns (Supplementary Fig. 1). CaMKII is especially suitable to decode high-frequency $\mathrm{Ca}^{2+}$ oscillations as its activation is sensitive to periodic changes in the range of $0.1-10 \mathrm{~s}$ [63]. For it is exactly at this range that differentiating cells in our experimental model exhibit spontaneous $\mathrm{Ca}^{2+}$ oscillations, it can be hypothesised that this pathway may mediate oscillation-linked activation of transcription factors to promote chondrogenic differentiation and matrix synthesis in primary chicken micromass cultures. However, further studies are needed to unequivocally confirm the involvement of CaMKII in decoding cytosolic $\mathrm{Ca}^{2+}$ oscillations in differentiating chondrocytes.

\subsection{Refined model of $\mathrm{Ca}^{2+}$ homeostasis in differentiating chondrocytes with respect to $\mathrm{Ca}^{2+}$ oscillations}

Based on results obtained in the present work and earlier data of our research group, as well as studies performed by others in this field, the following model is proposed to describe the generation and maintenance of spontaneous $\mathrm{Ca}^{2+}$ oscillations in differentiating chondrocytes (Fig. 8). Both $\mathrm{Ca}^{2+}$ entry across the plasma membrane and $\mathrm{Ca}^{2+}$ release from internal stores are required for the phenomenon, since oscillations disappeared when cultures were bathed in $\mathrm{Ca}^{2+}$-free extracellular solution, and also when internal $\mathrm{Ca}^{2+}$ stores were depleted. Therefore, at least three distinct mechanisms may be responsible for generation of $\mathrm{Ca}^{2+}$ oscillations.

First, an autocrine-paracrine purinergic regulatory loop during in vitro chondrogenesis first proposed in 2009 by our group [20] can be considered, similarly to what has been described in mature chondrocytes [53] or in MSCs [54]. We and others have reported that ATP is secreted by differentiating chondrocytes [20], possibly through connexin 43 hemichannels [64]; extracellular nucleotides may act on the two large superfamilies of P2 purinergic receptors: the ATP-gated ion channel-type P2X receptors, and the $G$ protein-coupled metabotropic P2Y receptors. Several subtypes of both P2X and P2Y receptors were found to be expressed by differentiating and mature chondrocytes [20,64]. Upon binding to P2 receptors, ATP may initiate two distinct $\mathrm{Ca}^{2+}$ signalling pathways: acting through metabotropic P2Y receptors leads to $\mathrm{Ca}^{2+}$ mobilisation from internal stores via the $\mathrm{PLC}_{\mathrm{IP}}$ pathway, while activation of ligand-gated $\mathrm{P} 2 \mathrm{X}$ receptors-that are bona fide ion channels-directly enables $\mathrm{Ca}^{2+}$ influx. Both pathways lead to the transient elevation of cytosolic $\mathrm{Ca}^{2+}$ concentration, eliminated by either active $\mathrm{Ca}^{2+}$ pump or exchange functions (sequestration into the ER by SERCA and NCX or into mitochondria by the mitochondrial calcium uniporter or mitochondrial NCX; or extrusion to the extracellular space by the plasma membrane $\mathrm{Ca}^{2+}$-ATPase, PMCA or NCX). 
Second, it should be noted that $\mathrm{P} 2 \mathrm{X}$ receptors are non-selective cation channels that mediate $\mathrm{Na}^{+}$influx, $\mathrm{K}^{+}$efflux and, to a lesser extent, $\mathrm{Ca}^{2+}$ influx, leading to cell membrane depolarisation [65]. This then triggers the activation of voltage-operated calcium channels (VOCCs), thus enabling further $\mathrm{Ca}^{2+}$ entry across the plasma membrane. VOCCs are also key (albeit not the pivotal) players involved in generation and/or maintenance of repetitive $\mathrm{Ca}^{2+}$ transients as their blockade by nifedipine alters the parameters of oscillations, although does not eliminate them. In turn, elevated cytosolic $\mathrm{Ca}^{2+}$ may also activate $\mathrm{Ca}^{2+}$ activated $\mathrm{K}^{+}$channels [66,67], which leads to membrane repolarisation that acts on other ion channels, e.g. voltage-dependent potassium channels $\left(\mathrm{K}_{\mathrm{V}}\right)$. We and others have shown that chondrocytes express mRNA transcripts and proteins of voltage-gated $\mathrm{K}^{+}$ion channels [68]; moreover, a switch between $K_{V} 1.1$ and $K_{V} 1.3$ plasma membrane protein expression is required for in vitro chondrogenesis [21]. In fact, two cell populations in terms of membrane potential distribution were observed in HDC: in one population, the mean membrane potential was more positive and showed greater fluctuations $(-39.0 \pm 4.1 \mathrm{mV})$ while in the other population, cells were much more hyperpolarised with significantly lower cell-tocell variance $(-72.2 \pm 1.5 \mathrm{mV})$ [21]. Periodic alterations in RMP may activate different subsets of VOCCs enabling cyclic $\mathrm{Ca}^{2+}$ influx that manifests in periodic $\mathrm{Ca}^{2+}$ oscillations. Obviously, other $\mathrm{Ca}^{2+}$ channels that enable $\mathrm{Ca}^{2+}$ entry across the plasma membrane (i.e. NMDA receptors, members of the TRP family, arachidonateregulated $\mathrm{Ca}^{2+}$ channels, etc.) may also contribute to maintenance of $\mathrm{Ca}^{2+}$ oscillations; however, their detailed analysis is yet to be performed.

The third mechanism may include many signalling pathways (i.e. $\mathrm{P} 2 \mathrm{Y}$ receptors, etc.) that converge on $\mathrm{Ca}^{2+}$ release from internal $\mathrm{Ca}^{2+}$ stores via activation of phospholipase $\mathrm{C}$ resulting in the generation of $\mathrm{IP}_{3}$ which then binds to the $\mathrm{IP}_{3}$ receptor in the ER membrane and promotes $\mathrm{Ca}^{2+}$ release. Store depletion in turn initiates SOCE via CRAC channels, which are activated through the binding of the ER $\mathrm{Ca}^{2+}$ sensors STIM1 and STIM2 to the CRAC channel protein Orai1 and/or other CRAC channels (for relevant recent reviews, see $[27,44]$ ). SOCE seems to be essential for $\mathrm{Ca}^{2+}$ oscillations as cells with depleted stores failed to exhibit periodic $\mathrm{Ca}^{2+}$ transients. However, $\mathrm{Ca}^{2+}$ release alone is insufficient for long-term maintenance of oscillations as transients disappeared when $\mathrm{Ca}^{2+}$ entry from the extracellular space was prevented by using $\mathrm{Ca}^{2+}$-free external bath solution. Therefore, SOCE is a key pathway required for sustained $\mathrm{Ca}^{2+}$ influx and store replenishment in differentiating chondrocytes.

Amongst other pathways, CaMKII enzyme subtypes, as well as the calcineurin-NFAT signalling axis may be involved in decoding information encoded by high-frequency $\mathrm{Ca}^{2+}$ oscillations, thus promoting differentiation of chondroprogenitor mesenchymal cells. Noteworthy that Sox9, the master transcription factor of chondrogenesis and sexual differentiation, can be translocated to the nucleus by binding to calmodulin during sex determination [69], suggesting that this $\mathrm{Ca}^{2+}$ dependent pathway may be involved in decoding $\mathrm{Ca}^{2+}$-oscillations in differentiating chondrocytes. However, the precise role of the above mechanisms played in this process is yet to be characterised.

It should be noted that $\mathrm{Ca}^{2+}$ entry and $\mathrm{Ca}^{2+}$ release are intimately connected and interdependent, and their precise role in generating/maintaining rapid $\mathrm{Ca}^{2+}$ oscillations cannot be discussed independently. We therefore hypothesise that the pathways discussed above act in coordination and are all indispensable to normal $\mathrm{Ca}^{2+}$ homeostasis of differentiating chondrocytes (although possibly to a variable extent), similarly to what has been described by Kawano et al. in human MSCs [54].

\subsection{Concluding remarks}

In this study, we provided evidence that rapid transient increases in cytosolic $\mathrm{Ca}^{2+}$ concentration are a common feature of cells in chicken primary HDC before and during differentiation (on days 1 and 2). It must be emphasised that these $\mathrm{Ca}^{2+}$ oscillations were spontaneous and did not require pharmacological stimulation by agonists, which is a relatively rare phenomenon amongst non-excitable cells where transient increases in cytosolic $\mathrm{Ca}^{2+}$ concentration generally occur following exposure to agonists. However, the molecular link between spontaneous high-frequency $\mathrm{Ca}^{2+}$ oscillations and regulation of chondrogenesis remains poorly characterised. Nevertheless, $\mathrm{Ca}^{2+}$ oscillations were gradually lost as chondroprogenitors became committed chondroblasts and then mature chondrocytes, suggesting they are only characteristic for differentiating cells of HDC. It is generally accepted that $\mathrm{Ca}^{2+}$ oscillations are involved in the differentiation of many non-excitable cells, including MSCs and articular chondrocytes. Moreover, the complex interrelation between cyclic changes of ATP and $\mathrm{Ca}^{2+} \mathrm{lev}-$ els has also been implicated in these cell types. Although several elements of the pathways involved, including $\mathrm{Ca}^{2+}$ sensitive protein kinases and phosphoprotein phosphatases (classic PKC, CaMKII, calcineurin), plasma membrane proteins ( $\mathrm{K}_{\mathrm{V}} 1.1, \mathrm{~K}_{\mathrm{V}} 1.3$, VOCC, P2X and P2Y receptors) and transcription factors (CREB, NFAT) have been identified in differentiating chondrocytes by our laboratory and others, the nature of their putative co-operation in generating and maintaining $\mathrm{Ca}^{2+}$ oscillations to govern differentiation remains elusive. These findings may prove to be useful for future research aimed at exploiting the regeneration capacity of chondroprogenitor cells found in both healthy [70] and diseased articular cartilage [71]. Extrapolation of our results regarding $\mathrm{Ca}^{2+}$ homeostasis of differentiating chondrocytes to cartilage regeneration or bioengineering from human mesenchymal stem cells may also contribute to recent advances in this field.

\section{Conflict of interest statement}

All authors disclose that there are neither any financial nor any personal relationships with other people or organisations that could inappropriately influence (bias) their work. There are no conflicts of interests.

\section{Acknowledgments}

Data acquired during fluorescent $\mathrm{Ca}^{2+}$ imaging were analysed by using an automatic event detection software developed by János Vincze. The authors are grateful to Mrs. Krisztina Bíró and Mrs. Róza Öri for excellent technical assistance, and to Máté Engler for his valuable contribution to the experimental work. We acknowledge Dr János Almássy and Csilla Somogyi for their useful comments and suggestions during the preparation of the manuscript. This work was supported by grants from the Hungarian Science Research Fund (OTKA CNK80709, OTKA NK 78398), TÁMOP-4.2.2.A-11/1/KONV-2012-0025 and TÁMOP4.2.2/B-10/1-2010-0024 projects implemented through the New Hungary Development Plan, co-financed by the European Union and the European Social Fund. J.F. is supported by a Bólyai fellowship. C.M. is supported by a Mecenatura grant (DEOEC Mec-9/2011) from the Medical and Health Science Centre, University of Debrecen, Hungary.

\section{Appendix A. Supplementary data}

Supplementary data associated with this article can be found, in the online version, at http://dx.doi.org/10.1016/j.ceca.2013.03.003. 
References

[1] H. Muir, The chondrocyte, architect of cartilage. Biomechanics, structure, function and molecular biology of cartilage matrix macromolecules, Bioessays 17 (1995) 1039-1048.

[2] V. Lefebvre, R.R. Behringer, B. de Crombrugghe, L-Sox5, Sox6 and Sox9 control essential steps of the chondrocyte differentiation pathway, Osteoarthritis and Cartilage 9 (Suppl. A) (2001) S69-S75.

[3] V.Y. Leung, B. Gao, K.K. Leung, I.G. Melhado, S.L. Wynn, T.Y. Au, N.W. Dung, J.Y. Lau, A.C. Mak, D. Chan, K.S. Cheah, SOX9 governs differentiation stagespecific gene expression in growth plate chondrocytes via direct concomitant transactivation and repression, PLoS Genetics 7 (2011) e1002356.

[4] J.A. Hanover, D.C. Love, W.A. Prinz, Calmodulin-driven nuclear entry: trigger for sex determination and terminal differentiation, Journal of Biological Chemistry 284 (2009) 12593-12597.

[5] S. Kawano, S. Shoji, S. Ichinose, K. Yamagata, M. Tagami, M. Hiraoka, Characterization of $\mathrm{Ca}(2+)$ signaling pathways in human mesenchymal stem cells, Cell Calcium 32 (2002) 165-174.

[6] C. Matta, J. Fodor, Z. Szijgyarto, T. Juhasz, P. Gergely, L. Csernoch, R. Zakany, Cytosolic free $\mathrm{Ca}^{2+}$ concentration exhibits a characteristic temporal pattern during in vitro cartilage differentiation: a possible regulatory role of calcineurin in Ca-signalling of chondrogenic cells, Cell Calcium 44 (2008) 310-323.

[7] M.J. Berridge, P. Lipp, M.D. Bootman, The versatility and universality of calcium signalling, Nature Reviews: Molecular Cell Biology 1 (2000) 11-21.

[8] K. Varani, M. De Mattei, F. Vincenzi, A. Tosi, S. Gessi, S. Merighi, A. Pellati, F. Masieri, A. Ongaro, P.A. Borea, Pharmacological characterization of P2X1 and $\mathrm{P} 2 \mathrm{X} 3$ purinergic receptors in bovine chondrocytes, Osteoarthritis and Cartilage 16 (2008) 1421-1429.

[9] D.M. Salter, M.O. Wright, S.J. Millward-Sadler, NMDA receptor expression and roles in human articular chondrocyte mechanotransduction, Biorheology 41 (2004) 273-281.

[10] I.M. Hdud, A.A. El-Shafei, P. Loughna, R. Barrett-Jolley, A. Mobasheri, Expression of transient receptor potential vanilloid (TRPV) channels in different passages of articular chondrocytes, International Journal of Molecular Sciences 13 (2012) 4433-4445.

[11] F. Guilak, H.A. Leddy, W. Liedtke, Transient receptor potential vanilloid 4: the sixth sense of the musculoskeletal system? Annals of the New York Academy of Sciences 1192 (2010) 404-409.

[12] J.L. Thompson, T.J. Shuttleworth, A plasma membrane-targeted cytosolic domain of STIM1 selectively activates ARC channels, an arachidonate-regulated store-independent Orai channel, Channels (Austin) 6 (2012) 370-378.

[13] E. Baljinnyam, M.S. De Lorenzo, L.H. Xie, M. Iwatsubo, S. Chen, J.S. Goydos, M.C. Nowycky, K. Iwatsubo, Exchange protein directly activated by cyclic AMP increases melanoma cell migration by a $\mathrm{Ca}^{2+}$-dependent mechanism, Cancer Research 70 (2010) 5607-5617.

[14] A.C. Elliott, Recent developments in non-excitable cell calcium entry, Cell Calcium 30 (2001) 73-93.

[15] B. Ye, $\mathrm{Ca}^{2+}$ oscillations and its transporters in mesenchymal stem cells, Physiological Research 59 (2010) 323-329.

[16] C. Fewtrell, $\mathrm{Ca}^{2+}$ oscillations in non-excitable cells, Annual Review of Physiology 55 (1993) $427-454$

[17] R.E. Dolmetsch, R.S. Lewis, C.C. Goodnow, J.I. Healy, Differential activation of transcription factors induced by $\mathrm{Ca}^{2+}$ response amplitude and duration, Nature 386 (1997) 855-858.

[18] T. Tomida, K. Hirose, A. Takizawa, F. Shibasaki, M. Iino, NFAT functions as a working memory of $\mathrm{Ca}^{2+}$ signals in decoding $\mathrm{Ca}^{2+}$ oscillation, EMBO Journal 22 (2003) 3825-3832.

[19] H. Sauer, C. Hofmann, M. Wartenberg, A.M. Wobus, J. Hescheler, Spontaneous calcium oscillations in embryonic stem cell-derived primitive endodermal cells, Experimental Cell Research 238 (1998) 13-22.

[20] J. Fodor, C. Matta, T. Juhasz, T. Olah, M. Gonczi, Z. Szijgyarto, P. Gergely, L. Csernoch, R. Zakany, Ionotropic purinergic receptor P2X4 is involved in the regulation of chondrogenesis in chicken micromass cell cultures, Cell Calcium 45 (2009) 421-430.

[21] Z. Varga, T. Juhasz, C. Matta, J. Fodor, E. Katona, A. Bartok, T. Olah, A. Sebe, L. Csernoch, G. Panyi, R. Zakany, Switch of voltage-gated $\mathrm{K}^{+}$channel expression in the plasma membrane of chondrogenic cells affects cytosolic $\mathrm{Ca}^{2+}$-oscillations and cartilage formation, PLoS ONE 6 (2011) e27957.

[22] C. Matta, R. Zakany, Calcium signalling in chondrogenesis: implications for cartilage repair, Frontiers in Bioscience (Scholar Edition) 5 (2013) 305-324.

[23] P.B. Ahrens, M. Solursh, R.S. Reiter, Stage-related capacity for limb chondrogenesis in cell culture, Developmental Biology 60 (1977) 69-82.

[24] M.T. Harper, A.W. Poole, Store-operated calcium entry and non-capacitative calcium entry have distinct roles in thrombin-induced calcium signalling in human platelets, Cell Calcium 50 (2011) 351-358.

[25] G. Grynkiewicz, M. Poenie, R.Y. Tsien, A new generation of $\mathrm{Ca}^{2+}$ indicators with greatly improved fluorescence properties, Journal of Biological Chemistry 260 (1985) 3440-3450.

[26] C. Matta, T. Juhasz, Z. Szijgyarto, B. Kolozsvari, C. Somogyi, G. Nagy, P. Gergely, R. Zakany, PKCdelta is a positive regulator of chondrogenesis in chicken high density micromass cell cultures, Biochimie 93 (2011) 149-159.

[27] S. Feske, CRAC channelopathies, Pflugers Archiv 460 (2010) 417-435.

[28] B. Darbellay, S. Arnaudeau, C.R. Bader, S. Konig, L. Bernheim, STIM1L is a new actin-binding splice variant involved in fast repetitive $\mathrm{Ca}^{2+}$ release, Journal of Cell Biology 194 (2011) 335-346.
[29] H. Shi, Y.D. Halvorsen, P.N. Ellis, W.O. Wilkison, M.B. Zemel, Role of intracellular calcium in human adipocyte differentiation, Physiological Genomics 3 (2000) $75-82$.

[30] J.D. San Antonio, R.S. Tuan, Chondrogenesis of limb bud mesenchyme in vitro: stimulation by cations, Developmental Biology 115 (1986) 313-324.

[31] O. Jacenko, R.S. Tuan, Chondrogenic potential of chick embryonic calvaria: I. Low calcium permits cartilage differentiation, Developmental Dynamics 202 (1995) $13-26$

[32] B. Zimmermann, K. Lange, P. Mertens, J.P. Bernimoulin, Inhibition of chondrogenesis and endochondral mineralization in vitro by different calcium channel blockers, European Journal of Cell Biology 63 (1994) 114-121.

[33] M.N. Phan, H.A. Leddy, B.J. Votta, S. Kumar, D.S. Levy, D.B. Lipshutz, S.H. Lee, W. Liedtke, F. Guilak, Functional characterization of TRPV4 as an osmotically sensitive ion channel in porcine articular chondrocytes, Arthritis and Rheumatism 60 (2009) 3028-3037.

[34] P. Singh, S. Doshi, J.M. Spaethling, A.J. Hockenberry, T.P. Patel, D.M. Geddes-Klein, D.R. Lynch, D.F. Meaney, N-methyl-D-aspartate receptor mechanosensitivity is governed by C terminus of NR2B subunit, Journal of Biological Chemistry 287 (2012) 4348-4359.

[35] E. Carafoli, Calcium-a universal carrier of biological signals. Delivered on 3 July 2003 at the Special FEBS Meeting in Brussels, The FEBS Journal 272 (2005) 1073-1089.

[36] S. Poiraudeau, M. Lieberherr, N. Kergosie, M.T. Corvol, Different mechanisms are involved in intracellular calcium increase by insulin-like growth factors 1 and 2 in articular chondrocytes: voltage-gated calcium channels, and/or phospholipase C coupled to a pertussis-sensitive G-protein, Journal of Cellular Biochemistry 64 (1997) 414-422.

[37] M. Shakibaei, A. Mobasheri, Beta1-integrins co-localize with Na, K-ATPase, epithelial sodium channels $(\mathrm{ENaC})$ and voltage activated calcium channels (VACC) in mechanoreceptor complexes of mouse limb-bud chondrocytes, Histology and Histopathology 18 (2003) 343-351.

[38] Y. Shao, M. Alicknavitch, M.C. Farach-Carson, Expression of voltage sensitive calcium channel (VSCC) L-type Cav1.2 (alpha1C) and T-type Cav3.2 (alpha1H) subunits during mouse bone development, Developmental Dynamics 234 (2005) 54-62.

[39] J. Xu, W. Wang, C.C. Clark, C.T. Brighton, Signal transduction in electrically stimulated articular chondrocytes involves translocation of extracellular calcium through voltage-gated channels, Osteoarthritis and Cartilage 17 (2009) 397-405.

[40] I. Raizman, J.N. De Croos, R. Pilliar, R.A. Kandel, Calcium regulates cyclic compression-induced early changes in chondrocytes during in vitro cartilage tissue formation, Cell Calcium 48 (2010) 232-242.

[41] I. Zahanich, E.M. Graf, J.F. Heubach, U. Hempel, S. Boxberger, U. Ravens, Molecular and functional expression of voltage-operated calcium channels during osteogenic differentiation of human mesenchymal stem cells, Journal of Bone and Mineral Research 20 (2005) 1637-1646.

[42] J.S. Ramsdell, Voltage-dependent calcium channels regulate GH4 pituitary cell proliferation at two stages of the cell cycle, Journal of Cellular Physiology 146 (1991) 197-206.

[43] T. Capiod, Cell proliferation, calcium influx and calcium channels, Biochimie 93 (2011) 2075-2079.

[44] S. Feske, E.Y. Skolnik, M. Prakriya, Ion channels and transporters in lymphocyte function and immunity, Nature Reviews: Immunology 12 (2012) 532-547.

[45] N. Rosemblit, M.C. Moschella, E. Ondriasa, D.E. Gutstein, K. Ondrias, A.R. Marks, Intracellular calcium release channel expression during embryogenesis, Developmental Biology 206 (1999) 163-177.

[46] C.E. Yellowley, C.R. Jacobs, H.J. Donahue, Mechanisms contributing to fluidflow-induced $\mathrm{Ca}^{2+}$ mobilization in articular chondrocytes, Journal of Cellular Physiology 180 (1999) 402-408.

[47] E. Yanagida, S. Shoji, Y. Hirayama, F. Yoshikawa, K. Otsu, H. Uematsu, M. Hiraoka, T. Furuichi, S. Kawano, Functional expression of $\mathrm{Ca}^{2+}$ signaling pathways in mouse embryonic stem cells, Cell Calcium 36 (2004) 135-146.

[48] J.F. Evans, C.L. Shen, S. Pollack, J.F. Aloia, J.K. Yeh, Adrenocorticotropin evokes transient elevations in intracellular free calcium $\left(\left[\mathrm{Ca}^{2+}\right]_{\mathrm{i}}\right)$ and increases basal $\left[\mathrm{Ca}^{2+}\right]_{\mathrm{i}}$ in resting chondrocytes through a phospholipase C-dependent mechanism, Endocrinology 146 (2005) 3123-3132.

[49] K. Funabashi, S. Ohya, H. Yamamura, N. Hatano, K. Muraki, W. Giles, Y. Imaizumi, Accelerated $\mathrm{Ca}^{2+}$ entry by membrane hyperpolarization due to $\mathrm{Ca}^{2+}$-activated $\mathrm{K}^{+}$channel activation in response to histamine in chondrocytes, American Journal of Physiology: Cell Physiology 298 (2010) C786-C797.

[50] P. D'Andrea, F. Vittur, Spatial and temporal $\mathrm{Ca}^{2+}$ signalling in articular chondrocytes, Biochemical and Biophysical Research Communications 215 (1995) 129-135.

[51] O. Brandman, J. Liou, W.S. Park, T. Meyer, STIM2 is a feedback regulator that stabilizes basal cytosolic and endoplasmic reticulum $\mathrm{Ca}^{2+}$ levels, Cell 131 (2007) 1327-1339.

[52] T.J. Shuttleworth, J.L. Thompson, O. Mignen, ARC channels: a novel pathway for receptor-activated calcium entry, Physiology (Bethesda) 19 (2004) 355-361.

[53] T. Kono, T. Nishikori, H. Kataoka, Y. Uchio, M. Ochi, K. Enomoto, Spontaneous oscillation and mechanically induced calcium waves in chondrocytes, Cell Biochemistry and Function 24 (2006) 103-111.

[54] S. Kawano, K. Otsu, A. Kuruma, S. Shoji, E. Yanagida, Y. Muto, F. Yoshikawa, Y. Hirayama, K. Mikoshiba, T. Furuichi, ATP autocrine/paracrine signaling induces calcium oscillations and NFAT activation in human mesenchymal stem cells, Cell Calcium 39 (2006) 313-324. 
G Model

YCECA 14721-16

16

J. Fodor et al. / Cell Calcium $x x x(2013) x x x-x x x$

126
126
126
126
126
127
127
127
127
127
127
127
127
127
127
128
128
128
128
128
128
128
128
128
128
129
129
129
128

[55] H.J. Kwon, Y. Ohmiya, K.I. Honma, S. Honma, T. Nagai, K. Saito, K. Yasuda, Synchronized ATP oscillations have a critical role in prechondrogenic condensation during chondrogenesis, Cell Death \& Disease 3 (2012) e278.

[56] H.J. Kwon, Extracellular ATP signaling via P2X(4) receptor and cAMP/PKA signaling mediate ATP oscillations essential for prechondrogenic condensation, Journal of Endocrinology 214 (2012) 337-348.

[57] J.A. Tsai, O. Larsson, H. Kindmark, Spontaneous and stimulated transients in cytoplasmic free $\mathrm{Ca}(2+)$ in normal human osteoblast-like cells: aspects of their regulation, Biochemical and Biophysical Research Communications 263 (1999) 206-212.

[58] C. Nguyen, M. Lieberherr, C. Bordat, F. Velard, D. Come, F. Liote, H.K. Ea, Intracellular calcium oscillations in articular chondrocytes induced by basic calcium phosphate crystals lead to cartilage degradation, Osteoarthritis and Cartilage 20 (2012) 1399-1408.

[59] M. Tomita, M.I. Reinhold, J.D. Molkentin, M.C. Naski, Calcineurin and NFAT4 induce chondrogenesis, Journal of Biological Chemistry 277 (2002) $42214-42218$.

[60] R. Zakany, Z. Szijgyarto, C. Matta, T. Juhasz, C. Csortos, K. Szucs, G. Czifra, T. Biro, L. Modis, P. Gergely, Hydrogen peroxide inhibits formation of cartilage in chicken micromass cultures and decreases the activity of calcineurin: implication of ERK1/2 and Sox9 pathways, Experimental Cell Research 305 (2005) 190-199.

[61] P. De Koninck, H. Schulman, Sensitivity of CaM kinase II to the frequency of $\mathrm{Ca}^{2+}$ oscillations, Science 279 (1998) 227-230.

[62] A. Shimazaki, M.O. Wright, K. Elliot, D.M. Salter, S.J. Millward-Sadler, Calcium/calmodulin-dependent protein kinase II in human articular chondrocytes, Biorheology 43 (2006) 223-233.

[63] G. Dupont, A. Goldbeter, CaM kinase II as frequency decoder of $\mathrm{Ca}^{2+}$ oscillations, Bioessays 20 (1998) 607-610.
[64] M.M. Knight, S.R. McGlashan, M. Garcia, C.G. Jensen, C.A. Poole, Articular chondrocytes express connexin 43 hemichannels and P2 receptors-a putative mechanoreceptor complex involving the primary cilium? Journal of Anatomy 214 (2009) 275-283.

[65] L. Erb, Z. Liao, C.I. Seye, G.A. Weisman, P2 receptors: intracellular signaling, Pflugers Archiv 452 (2006) 552-562.

[66] R.B. Clark, C. Kondo, D.D. Belke, W.R. Giles, Two-pore domain K(+) channels regulate membrane potential of isolated human articular chondrocytes, The Journal of Physiology 589 (2011) 5071-5089.

[67] A. Mobasheri, R. Lewis, J.E. Maxwell, C. Hill, M. Womack, R. Barrett-Jolley, Characterization of a stretch-activated potassium channel in chondrocytes, Journal of Cellular Physiology 223 (2010) 511-518.

[68] R.B. Clark, N. Hatano, C. Kondo, D.D. Belke, B.S. Brown, S. Kumar, B.J. Votta, W.R. Giles, Voltage-gated $\mathrm{K}^{+}$currents in mouse articular chondrocytes regulate membrane potential, Channels (Austin) 4 (2010) 179-191.

[69] A. Argentaro, H. Sim, S. Kelly, S. Preiss, A. Clayton, D.A. Jans, V.R. Harley, A SOX9 defect of calmodulin-dependent nuclear import in campomelic dysplasia/autosomal sex reversal, Journal of Biological Chemistry 278 (2003) 33839-33847.

[70] R. Williams, I.M. Khan, K. Richardson, L. Nelson, H.E. McCarthy, T. Analbelsi, S.K. Singhrao, G.P. Dowthwaite, R.E. Jones, D.M. Baird, H. Lewis, S. Roberts, H.M. Shaw, J. Dudhia, J. Fairclough, T. Briggs, C.W. Archer, Identification and clonal characterisation of a progenitor cell sub-population in normal human articular cartilage, PLoS ONE 5 (2010) e13246.

[71] S. Koelling, J. Kruegel, M. Irmer, J.R. Path, B. Sadowski, X. Miro, N. Miosge, Migratory chondrogenic progenitor cells from repair tissue during the later stages of human osteoarthritis, Cell Stem Cell 4 (2009) 324-335.
1293

1294

1295

1296

1298

1299

1300

1301

1302

1304

1305

1306

1307
1308

1309

1310

1311

1312

1313

1314
1315

1316

1317

1318

1319

Please cite this article in press as: J. Fodor, et al., Store-operated calcium entry and calcium influx via voltage-operated calcium channels regulate intracellular calcium oscillations in chondrogenic cells, Cell Calcium (2013), http://dx.doi.org/10.1016/j.ceca.2013.03.003 